\title{
1 Biochar interferes with kiwifruit Fe-nutrition in calcareous soil
}

2

3 Original Article/Full-length paper

4 Authors:

$5 \quad$ Giovambattista Sorrenti ${ }^{\mathrm{a}}$, g.sorrenti@unibo.it

6 Caroline A. Masiello ${ }^{\mathrm{b}}$, masiello@ rice.edu

$7 \quad$ Moreno Toselli ${ }^{\mathrm{a}}$, moreno.toselli@unibo.it

8

$9 \quad$ Author's affiliation and address:

$10{ }^{a}$ Department of Agricultural Sciences, University of Bologna, viale G. Fanin 44, 40127

11 Bologna, Italy

$12{ }^{\mathrm{b}}$ Departments of Earth Science, BioSciences and Chemistry, Rice University, Houston, 13 Texas 77005, USA

15 Corresponding author:

16 Giovambattista Sorrenti

17 Department of Agricultural Sciences, University of Bologna, viale G. Fanin 44, 40127

18 Bologna, Italy

19 E-mail: g.sorrenti@unibo.it

20 Telephone number: +390512096426

$21 \quad$ Fax number: +390512096401 


\section{Abstract}

We combined lab experiments, a 2-year pot experiment, light microscopy and X-ray photoelectron spectroscopic measurements to understand the fate of Fe in biocharamended soils with, and without, three sustainable Fe-fertilization strategies (siderite, aqueous extract of Amaranthus retroflexus either alone or enriched with $\mathrm{FeSO}_{4}$ ). In addition, we examined biochar effects on plant-available micronutrients using metal $\mathrm{Fe}$. We also assessed nonlinear interactions between biochar and Fe management strategies, evaluating the effectiveness of sustainable fertilization strategies in improving $\mathrm{Fe}$ nutrition of kiwifruit vines under Fe-stressed conditions. Fe chlorosis symptoms of potcropped kiwifruit vines were pronounced in the biochar-amended soils, especially during the first season. However, the biochar rate adopted in this study was relatively high $\left(5 \mathrm{~g} \mathrm{~kg}^{-1} \mathrm{~W} \mathrm{w}^{-1}\right)$ while the real impact of this strategy may change at lower rates. In the lab, increasing biochar rates progressively removed dissolved micronutrients from solution. Light microscopy revealed rust-colored patches on the biochar surface exposed to a Fe source in solution and XPS analyses confirmed that the biochar surface had become coated with $\mathrm{Fe}$ and $\mathrm{O}$ in ratios consistent with the formation of $\mathrm{Fe}$ (hydr)oxides. Although we investigated one specific biochar, our results suggest that some of redox reactions can act to form a micronutrient sink on the biochar surface. This mechanism likely contributed to binding soil Fe (through reactive functional groups on its surface) into plant-unavailable forms, promoting the occurrence of $\mathrm{Fe}$ chlorosis symptoms of kiwifruit vines grown in soils amended with biochar. We also confirmed the effectiveness of siderite and A. retroflexus extract enriched with $\mathrm{FeSO}_{4}$ in alleviating the occurrence of Fe-deficiency symptoms in kiwifruit vines.

Keywords: Biochar, calcareous soil, soil extractable Fe, redox reaction, Fe chlorosis 


\section{INTRODUCTION}

Biochar is produced via biomass pyrolysis (heating in the absence of $\mathrm{O}_{2}$ ) typically at temperatures below $700^{\circ} \mathrm{C}$ (Atkinson et al., 2010). Used as a soil conditioner, this Crich material has been proposed as a potential strategy to mitigate climate change and benefit both soil fertility and crop yield (Atkinson et al., 2010; Jeffery et al., 2011; Laird, 2008; Lehmann, 2007 and references therein). While it is widely accepted that biochar interacts with the soil mineral matrix likely through multiple processes, specific mechanisms driving the biochar-induced interactions are not fully understood (Joseph et al., 2010). Recently it has been suggested that one gram of biochar can take up and release several hundred micromoles of electrons (Klüpfel et al., 2014; Joseph et al., 2015 and literature therein) and participate in redox-mediated reactions in the soil, indicating that biochar could potentially affect biogeochemical cycles in soil, pollutant degradation, contaminant mobilization, abiotic formation of humic structures not only by changing soil physical and chemical properties, but also by mediating electron transfer processes (i.e., as an electron shuttle) (Graber et al., 2014) altering, among others, the iron $(\mathrm{Fe})$ cycle in soils (Kappler et al., 2014).

So far most of the scientific evidence showing benefits from the use of biochar as a soil conditioner comes from tropical and subtropical environments characterized by acid, weathered, and low fertility soils (Jeffery et al., 2011), but alteration of soil Fe cycling is most likely to generate observable plant impacts in alkaline or calcareous soils because Fe solubility is reduced in these systems. Calcareous, high $\mathrm{pH}$ soils represent approximately $39 \%$ of world soils, and are agriculturally important in a number of areas (Çelik and Katkat, 2010). In these soils Fe in solution precipitates as scarcely soluble Fe-hydroxides, as a consequence of the high $\mathrm{pH}$ and the active lime fraction (Römheld 
and Nikolic, 2007). In addition, the enzymatic activity of the root $\mathrm{Fe}^{\mathrm{III}}$-chelate reductase, responsible for the reduction of the $\mathrm{Fe}^{\mathrm{III}}$ to $\mathrm{Fe}^{\mathrm{II}}$, is dramatically compromised (Susin et al., 1996), limiting the availability of the ionic Fe form absorbable by roots of dicots (Römheld and Marschner, 1986). Limited Fe availability negatively affects leaf chlorophyll (Chl) concentration (Abadía and Abadía, 1993), leaf water relations (Eichert et al., 2010; Fernández et al., 2008), and may reduce yield and fruit quality (ÁlvarezFernández et al., 2006; Sorrenti et al., 2012 and literature therein), including in kiwifruit, which is considered among the most susceptible crops to this disorder (Tagliavini and Rombolà, 2001). Italy is one of the world largest kiwifruit producers. Kiwifruit represents a remunerative crop for growers and in the northern part of the Country, it is grown mainly on alkaline-calcareous soils, thereby plant Fe-nutrition must be carefully managed to avoid significant yield and fruit quality losses. Typically, growers use either soil- or foliar-applied synthetic Fe-chelates to manage plant Fe nutrition. Although effective at preventing or curing Fe-chlorosis (Abadía et al., 2011; Lucena 2006;) these soil chelates induce only a short-lasting re-greening, are expensive (Tagliavini and Rombolà, 2001) and pose environmental concerns (Grčman et al., 2001; Nörtemann, 1999) since they can be easily leached. Because of this, the development of cost-effective and environmentally friendly strategies to overcome Fechlorosis is of interest (Pestana et al., 2003). A more environmentally tolerable alternative may be the aqueous vegetal extract of Amaranthus retroflexus, which significantly increased the amount of $\mathrm{Fe}$ extracted from soil compared to deionized water $\left(\mathrm{DI}-\mathrm{H}_{2} \mathrm{O}\right)$ and improved $\mathrm{Fe}-$ nutrition of pear trees (Sorrenti et al., 2011). This response was attributed to natural Fe chelating compounds released by the Amaranthus spp. tissues (Matocha and Pennington, 1982; Matocha, 1984). The performance of the 
A. retroflexus extract may be improved by exposing it to Fe salts prior to soil amendment (e.g. $\mathrm{FeSO}_{4}$ ). On the other hand, when applied alone $\mathrm{Fe}$ salts are of little agronomic value since they precipitate into highly insoluble compounds (Tagliavini et al., 2000) becoming inefficient in providing any remediation of Fe-chlorosis. However, natural chelators (like those present in A. retroflexus extract) may stabilize $\mathrm{Fe}$ in a plantavailable form (Matocha and Pennington, 1982).

Another option may be soil-applied synthetic minerals such as vivianite $\left(\mathrm{Fe}_{3}\left(\mathrm{PO}_{4}\right)_{2} .8 \mathrm{H}_{2} \mathrm{O}\right)$ and siderite $\left(\mathrm{a} \mathrm{Fe}(\mathrm{II})\right.$ carbonate $\left.\left(\mathrm{FeCO}_{3}\right)\right)$, whose slow release of $\mathrm{Fe}$ achieved a long-lasting prevention of Fe-chlorosis in different crops (Cañasveras et al., 2014; Rosado et al., 2002; Sánchez-Alcalá et al., 2012a, 2012b;). Reacting with soil carbonate, these minerals form poorly crystalline Fe oxides (Roldán et al., 2002; Sánchez-Alcalá et al., 2012a), which are considered among the main source of Fe to plants (de Santiago and Delgado, 2006).

When biochar is combined with other amendments, results are sometimes not additive (Lecroy et al., 2013) and because of this, it is not possible to extrapolate the response of an ecosystem to combinations of biochar and other amendments based on the ecosystem's response to each amendment individually. Here the aims of this study were to: i) determine mechanisms of interactions between micronutrients and biochar (with emphasis on $\mathrm{Fe}$ ), ii) investigate the effectiveness of sustainable fertilization strategies in preventing $\mathrm{Fe}$-chlorosis of kiwifruit vines grown in a calcareous soil, and iii) use an improved understanding of Fe-biochar interactions to predict the potential for nonlinear interactions between biochar and Fe management strategies. 


\section{MATERIALS AND METHODS}

121

122

123

124

125

126

127

\subsection{Interaction between biochar and Fe nutrition on kiwifruit vines}

\subsubsection{Experimental design and growth conditions}

We performed a 2-year (2011-12) outdoors experiment at the experimental station of the University of Bologna (located in Cadriano, $44^{\circ} 55^{\prime} \mathrm{N}, 11^{\circ} 40^{\prime} \mathrm{E}, 36 \mathrm{~m}$ a.s.1.) on 1-year old micropropagated kiwifruit vines (Actinidia deliciosa cv. Hayward) grown in $5.2 \mathrm{~L}$ pots filled with a heavy alkaline-calcareous soil (Table 1). Vines were trained as in a single shoot, watered daily (in summer) by microirrigation to return the evapotranspiration (ETo) rate as estimated by a class A evaporation pan and the specific crop coefficient $(\mathrm{Kc})$ for kiwifruit and covered with shade netting which allowed a light intensity of 73.500 lux (measured under the net in summer at noon on a sunny day).

Except for Fe, plant nutrient requirements, nitrogen $(\mathrm{N})$, phosphorus $(\mathrm{P})$, potassium $(\mathrm{K})$ and magnesium $(\mathrm{Mg})$ were satisfied by periodic supply of a nutrient solution prepared by mineral sources (e.g. NPK complexes, $\mathrm{MgNO}_{3}$ ) and distributed by fertigation.

During the experiment, we did not spray the canopy with fertilizers or pesticides and we manually removed weeds from pots. The experiment was arranged in a completely randomized factorial experimental design with 6 replicates (single vine) and 2 factors: a) fertilization (5 levels) and b) biochar (2 levels). We compared the following fertilization treatments: a) untreated control; b) commercial Fe-chelate $\left(1.0 \mathrm{~g} \mathrm{~L}^{-1}\right.$ of commercial Fe-ethylenediamine-N,N'-bis-(o-hydroxyphenylacetic) acid (Fe-EDDHA) with a Fe content of $6 \%$ mostly in the ortho-ortho isomer); c) synthetic siderite (1.0 g of suspension per $\mathrm{kg}$ of soil); d) aqueous extract of $A$. retroflexus at a rate of $30 \mathrm{~g}$ (dry weight $-\mathrm{dw}) \mathrm{L}^{-1}$, and e) aqueous extract of $A$. retroflexus at a rate of $30 \mathrm{~g}(\mathrm{dw}) \mathrm{L}^{-1}$ mixed with $\mathrm{Fe}(\mathrm{II})$ sulfate heptahydrate $\left(\mathrm{FeSO}_{4} \cdot 7 \mathrm{H}_{2} \mathrm{O}\right)$ at a rate of $2 \mathrm{~g} \mathrm{~L}^{-1}$. Table 3 summarizes treatments, rates and timing of application. 
145 Synthetic siderite was prepared by mixing $40 \mathrm{~g} \mathrm{~L}^{-1}$ of $\mathrm{K}$ carbonate $\left(\mathrm{K}_{2} \mathrm{CO}_{3}\right)$ (Sigma-

146 Aldrich) into a pot containing $80 \mathrm{~g} \mathrm{~L}^{-1}$ of $\mathrm{Fe}(\mathrm{II})$ sulfate-heptahydrate $\left(\mathrm{FeSO}_{4} .7 \mathrm{H}_{2} \mathrm{O}\right)$

147 which generated a brownish green suspension containing $34 \mathrm{~g} \mathrm{~L}^{-1}$ of siderite. The

148 solution was continuously stirred and the suspension was mixed into the soil only once

149 at planting at a rate of $125 \mathrm{~mL}$ per pot in order to apply $1 \mathrm{~g}$ of siderite per $\mathrm{kg}$ of soil.

150 The aqueous A. retroflexus extract was prepared and characterized as described by

151 Sorrenti et al. (2011). Briefly, the dried powder of A. retroflexus was macerated in tap

152 water $\left(\mathrm{pH} 7.4 ; \mathrm{Fe}<0.08 \mathrm{mg} \mathrm{L}^{-1}\right)$ at least $24 \mathrm{~h}$ before its application, maintaining the

153 suspension at room temperature and in the dark. The aqueous A. retroflexus vegetal

154 extract alone or enriched were applied at weekly intervals 4 and 5 times in the first and

155 second season, respectively, starting from bud burst and at a rate of $200 \mathrm{~mL} \mathrm{plant}^{-1}$.

156 At the same time as the aqueous vegetal extract applications, Fe-chelate treated plants

157 received $200 \mathrm{~mL}$ plant $^{-1}$ of Fe-chelate solution while untreated and siderite treated

158 plants received the same amount of tap water.

159 We did not provide a treatment based on the mere addition of soil-applied $\mathrm{FeSO}_{4}$

160 because it is already known that the supply of inorganic Fe-salts is inefficient in high

$161 \mathrm{pH}$ (e.g. alkaline-calcareous) soils in enhancing Fe availability, due to the rapid

162 transformation of most of the applied Fe into highly insoluble compounds such as

163 Fe(III)-hydroxides (Tagliavini et al., 2000).

164 Fertilization strategies were either applied to vines grown in: i) unamended soil or ii)

165 soil amended with biochar at a rate of $50 \mathrm{~g}$ (fresh weight (fw) $\mathrm{kg}^{-1}\left(\mathrm{w} \mathrm{w}^{-1}\right)$ equal to $52 \mathrm{t}$

$166 \mathrm{fw} \mathrm{ha} \mathrm{f}^{-1}$ (considering a treated area of $2 \mathrm{~m}$ wide along vine row in a commercial kiwifruit

167 orchard with a $3 * 5 \mathrm{~m}$ spacing (667 vines ha ${ }^{-1}$ ), soil incorporation up to $0.20 \mathrm{~m}$ depth and

168 a specific soil weight of $1.3 \mathrm{t} \mathrm{m}^{-3}$ ). The biochar we used in this experiment consisted of 
small chunks obtained from a mixed feedstock of fruit tree wood prunings, with a prevalence of peach (Prunus persica L.) and grapevine (Vitis vinifera L.) pyrolyzed in a commercial kiln plant at approximately $550^{\circ} \mathrm{C}$ and atmospheric pressure (Table 2).

\subsubsection{Fe-chlorosis incidence, plant nutritional status and plant biomass}

We estimated the incidence of Fe-chlorosis periodically by the determination of the leaf Chl concentration. Estimations were performed on the first completely expanded apical leaf per shoot by a hand-held Chl meter (SPAD 502, Minolta Co. LTD, Osaka, Japan).

Shoot length was also periodically recorded. In July of the second season, we randomly collected fully expanded leaves from each vine. We removed petioles and then washed leaf laminas in a $0.1 \mathrm{~N} \mathrm{HCl}$ solution supplemented with a surfactant (Tween 20) at a rate of $1 \mathrm{~mL} \mathrm{~L}^{-1}$. We rinsed samples abundantly in DI- $\mathrm{H}_{2} \mathrm{O}$, and then oven-dried $\left(65^{\circ} \mathrm{C}\right)$ until constant weight and milled them (0.2 mm mesh). We determined leaf macro ( $\mathrm{N}, \mathrm{P}$, $\mathrm{K}$, calcium $(\mathrm{Ca}), \mathrm{Mg})$ and micro $(\mathrm{Fe}$, manganese $(\mathrm{Mn})$, zinc $(\mathrm{Zn})$ and copper $(\mathrm{Cu}))$ nutrient concentration. Total $\mathrm{N}$ concentration was determined by the Kjeldahl method (Schuman et al., 1973) by mineralizing $1.5 \mathrm{~g}$ of sample with $12 \mathrm{~mL}$ of a 95:5 $\left(\mathrm{v} \mathrm{v}^{-1}\right)$ $\mathrm{H}_{2} \mathrm{SO}_{4}: \mathrm{H}_{3} \mathrm{PO}_{3}$ mixture, at $420{ }^{\circ} \mathrm{C}$, for $180 \mathrm{~min}$ and subsequent distillation with $32 \%$ (v $\left.\mathrm{v}^{-1}\right) \mathrm{NaOH}$ and titration with $0.2 \mathrm{M} \mathrm{HCl}$. Phosphorus was spectrophotometrically quantified at $700 \mathrm{~nm}$, through extract mineralization (Saunders and Williams 1955) of $0.5 \mathrm{~g}$ of tissue with $96 \%\left(\mathrm{v} \mathrm{v}^{-1}\right) \mathrm{H}_{2} \mathrm{SO}_{4}$ and $35 \%\left(\mathrm{v} \mathrm{v}^{-1}\right)$ oxygen peroxide $\left(\mathrm{H}_{2} \mathrm{O}_{2}\right)$, and subsequent neutralization with $0.1 \mathrm{M} \mathrm{NaOH}$ enriched with $0.1 \mathrm{M}$ ascorbic acid, $32 \mathrm{mM}$ ammonium molybdate, $2.5 \mathrm{M}$ sulfuric acid and $3 \mathrm{mM}$ potassium antimonyl tartrate trihydrate (Sigma-Aldrich) to develop a phospho-molybdic blue color. Metal concentrations were determined by atomic absorption spectrophotometry (AAS) (Varian 
AA200, Mulgrave, Victoria, Australia) after wet digestion according to USEPA Method 3052 (Kingston 1988). To this end, $0.5 \mathrm{~g}$ of dry matter were mineralized in an Ethos TC microwave labstation (Milestone, Bergamo, Italy) by adding $8 \mathrm{~mL}$ of nitric acid (65\%) and $2 \mathrm{~mL}$ of $\mathrm{H}_{2} \mathrm{O}_{2}(30 \%)$ at $180{ }^{\circ} \mathrm{C}$. Lanthanum chloride $\left(\mathrm{LaCl}_{3}\right.$ at $\left.10 \%\right)$ and cesium chloride $(\mathrm{CsCl}$ at $5 \%)$ solutions were added to the samples at ratios of 20 and $4 \%$, respectively prior to $\mathrm{K}, \mathrm{Ca}$ and $\mathrm{Mg}$ readings. At the end of the second season, vines were harvested and divided into shoots and roots (including stem), oven-dried at $65^{\circ} \mathrm{C}$ until constant weight.

\subsubsection{Soil pH and soil extractable micronutrients}

At the end of the experiment, a soil sample $(1 \mathrm{~kg})$ was collected from each pot, ovendried $\left(105^{\circ} \mathrm{C}\right)$, ground $(1 \mathrm{~mm}$ mesh) and used to determine soil $\mathrm{pH}$ and soil diethylenetriamine-pentaacetic-acid (DTPA) (Lindsay and Norwell 1978) extractable $\mathrm{Fe}, \mathrm{Mn}, \mathrm{Cu}$ and $\mathrm{Zn}$ concentrations. We also determined soil extractable Fe using DI$\mathrm{H}_{2} \mathrm{O}$ as eluent. For both eluents (DI- $\mathrm{H}_{2} \mathrm{O}$ and DTPA), $80 \mathrm{~mL}$ were added to glass flasks containing $40 \mathrm{~g}(\mathrm{dw})$ of soil, shaken $2 \mathrm{~h}$, decanted and then filtered (Whatman 42). The micronutrient concentration in the supernatant was determined by AAS (Varian AA200, Mulgrave, Victoria, Australia). Soil $\mathrm{pH}$ was determined in a soil: $\mathrm{DI}-\mathrm{H}_{2} \mathrm{O}$ solution at a rate of 1:2.5 $\left(\mathrm{w} \mathrm{w}^{-1}\right) .10 \mathrm{~g}$ of soil were added to $25 \mathrm{~mL}$ of $\mathrm{DI}-\mathrm{H}_{2} \mathrm{O}$, then stirred $1 \mathrm{~h}$ prior readings under continuous stirring by $\mathrm{pH}$ meter (Crison, $\mathrm{pH}-$ Meter BasiC 20, Barcelona, Spain).

\subsection{Biochar micronutrients release and retention potential}

We used the same biochar batch described in the previous experiment. However, we first sieved it to remove ash and impurities and to homogenize the size of the fragments 
to a range of 2-7.5 $\mathrm{mm}$. We washed the biochar to reduce ash and tar content by adding $4 \mathrm{~L}$ of DI- $\mathrm{H}_{2} \mathrm{O}$ to $200 \mathrm{~g}$ of biochar (with 3 replicates) and shaking $30 \mathrm{~min}$ at $100 \mathrm{rpm}$ with an orbital shaker. After every washing we collected the supernatant and analyzed it for electrical conductivity (EC) (Crison, Conductivity meter 524, Barcelona, Spain) which resulted at the end $51.5 \pm 1.64 \mu \mathrm{S} \mathrm{cm}^{-1}$ (avg. $\pm \mathrm{SE} \mathrm{n}=3$ ). These washing steps were necessary since solutions obtained with unwashed biochar, quickly became heavily oily with fine solids floating on, hard to be filtered or analyzed. The biochar fragments were then oven-dried at $30^{\circ} \mathrm{C}$. After this, $25 \mathrm{~mL}$ of DI- $\mathrm{H}_{2} \mathrm{O}$ were added to glass flasks containing 4, 10, 20, 30 and $40 \mathrm{~g} \mathrm{~L}^{-1}$ of biochar, with 3 replicates. Four additional series of flasks with the same biochar rates $\left(4,10,20,30\right.$ and $\left.40 \mathrm{~g} \mathrm{~L}^{-1}\right)$ with 5 replicates were added to $25 \mathrm{~mL}$ solutions containing $10 \mathrm{mg} \mathrm{L}^{-1}$ of one of the following cations: $\mathrm{Fe}, \mathrm{Mn}, \mathrm{Zn}$ or $\mathrm{Cu}$. These solutions were prepared by diluting analytical grade $\mathrm{FeCl}_{3} .6 \mathrm{H}_{2} \mathrm{O}, \mathrm{MnCl}_{2} .4 \mathrm{H}_{2} \mathrm{O}, \mathrm{ZnCl}_{2}$ and $\mathrm{CuSO}_{4}$ in $0.12 \mathrm{~N} \mathrm{HCl}$ standard solutions (J.T. Baker), used as a source of micronutrients. The $\mathrm{pH}$ of all solutions was adjusted by sodium hydroxide $(\mathrm{NaOH})$ to $7.2 \pm 0.1$ and then flasks were shaken on an orbital shaker for $120 \mathrm{~min}$ at $90 \mathrm{rpm}$. The supernatant was then filtered (Whatman 42) and analyzed for micronutrients by AAS (Varian AA200, Mulgrave, Victoria, Australia).

\subsection{Biochar surface chemistry change as affected by exposure to Fe metal}

We added three medium-sized, washed biochar fragments, as described above, to $25 \mathrm{~mL}$ of DI- $\mathrm{H}_{2} \mathrm{O}$ or to a solution made of DI- $\mathrm{H}_{2} \mathrm{O}$ plus $100 \mathrm{mg}$ of $\mathrm{Fe}$ dust $(>350 \mu \mathrm{m}$, obtained from a commercial Fe bar), in 3 replicates. After one week, fragments were removed 
and oven-dried at $65^{\circ} \mathrm{C}$. One biochar fragment per replicate was analyzed by X-ray

241 photoelectron spectroscopy (XPS). The top $5 \mathrm{~nm}$ of the biochar surface was analyzed

242 for relative $\mathrm{Fe}$, oxygen $(\mathrm{O})$ and $\mathrm{C}$ atomic concentration (at\%) using a PHI Quantera

243 XPS with aluminum (Al) X-ray source at $1486.6 \mathrm{eV}$ and $49.2 \mathrm{~W}$. The beam diameter

244 was $200.0 \mu \mathrm{m}$ and the pass energy $26 \mathrm{eV}$. XPS spectra were analyzed using a nonlinear

245 least-squares curve-fitting program with a Gaussian-Lorentzian mixed function to

246 optimize the spectra which were processed using MultiPak data analysis software

247 (MultiPak V7.0.1, 04 Mar 16, Ulvac-Phi, Inc., 1994-2004).

248

\subsection{Statistical analyses}

Pot experiment data were evaluated by analysis of variance according to a factorial randomized block design with 2 factors: fertilization ( 5 levels) and biochar (2 levels)

with 6 replicates. When analysis of variance showed a statistical effect (at $\mathrm{P} \leq 0.05$ ),

means were separated by Student-Newman-Keuls Test (SNK); when interaction

between fertilization treatment and biochar was significant, 2 times standard error of means (SEM) was used as the minimum difference between two statistically different means (Saville and Rowarth 2008). Coefficient of determination $\left(r^{2}\right)$ between biochar rate and micronutrients concentration was calculated in the lab experiment using linear regression analysis. Statistical analyses were performed using SAS software (SAS

259 Institute Inc., Cary, NC)

\section{RESULTS}

262 Generally, our results point to biochar acting as a sink for the micronutrients $\mathrm{Fe}, \mathrm{Mn}$, $263 \mathrm{Cu}$, and $\mathrm{Zn}$, which were effectively removed from the solutions. 


\subsection{Interaction between biochar and Fe nutrition in kiwifruit}

266

267

\subsubsection{Fe chlorosis incidence, vine nutritional status and plant biomass}

Pronounced leaf Fe chlorosis symptoms characterized untreated vines in both seasons (as estimated by the lowest values of leaf Chl content). Without interaction between the two factors (fertilization and biochar) and independently of the amendment with biochar, all fertilization strategies were effective in significantly increasing leaf Chl content except for the aqueous extract of $A$. retroflexus alone (data are available in Table S1 and S2 of the supplementary material).

The Fe-chelate soil application consistently produced the greatest SPAD index. Siderite and $A$. retroflexus enriched with $\mathrm{FeSO}_{4}$ yielded $\mathrm{SPAD}$ values similar to those of the $\mathrm{Fe}-$ chelate treated-plants, particularly in the first season, whereas A. retroflexus alone was ineffective in preventing Fe chlorosis (data not shown).

Leaf Fe-deficiency symptoms were noticeable in plants grown in biochar amended soil, but only in the first season (Fig. 1).

All control and aqueous extract A. retroflexus-alone treated vines died in the summer of the second season, independently of the presence of biochar in soil.

Shoot length was significantly increased by fertigation with aqueous extract of $A$. retroflexus $+\mathrm{FeSO}_{4}$ in the first season (data are available in Table $\mathrm{S} 3$ of the supplementary material) while in the second year, it was promoted mainly by Fe-chelate and, to a less extent, by $A$. retroflexus $+\mathrm{FeSO}_{4}$ and siderite compared to control plants (data are available in Table S3 of the supplementary material).However, at the end of the experiment, no significant differences were observed among the remaining strategies (data are available in Table S3 of the supplementary material). 
Independently of the fertilization and without interaction between factors, shoot growth was significantly depressed by the presence of biochar in soil in the measurements of Sep-2011 and Jun-2012 (Fig. 1).

The application of Fe-chelate and A. retroflexus $+\mathrm{FeSO}_{4}$ resulted in higher total plant biomass compared to other strategies (Table 4). However, Fe-chelate significantly promoted shoot biomass while treatment with $A$. retroflexus $+\mathrm{FeSO}_{4}$ increased root (including stem) biomass compared with siderite at the end of the experiment (Table 4). Nevertheless, no statistical differences were recorded between the highest values (Table 4). The 12 untreated as well as the 12 A. retroflexus-alone treated plants died in summer of the second season, and therefore no shoots could be sampled at plant harvest. In addition, a poorly developed root system was recovered from these pots (Table 4). The addition of biochar to the soil did not affect organs or total plant biomass, without interaction between factors (Table 4).

Leaf $\mathrm{K}$ concentration was decreased in plants treated with Fe-chelate compared to other treatments while a significant interaction between treatment and biochar occurred for leaf $\mathrm{Mg}, \mathrm{Fe}$ and $\mathrm{Mn}$ (Table 5). When soil was amended with biochar leaf $\mathrm{Mg}$ and $\mathrm{Fe}$ concentrations were significantly decreased in plants treated with Fe-chelate and the aqueous extract enriched with $\mathrm{FeSO}_{4}$, but not with siderite (Table 5). Only in unamended soil leaf $\mathrm{Mg}$ concentration was significantly increased by Fe-chelate compared to the aqueous extract enriched and siderite (Table 5). The supply of Fechelate dramatically increased leaf Fe and decreased leaf Mn concentration compared to other treatments, independently of the substrate (Table 5). Similarly, leaf Fe concentration was higher in plants fertilized with the suspension of siderite in comparison to those fertigated with the aqueous extract enriched (Table 5). The same 
trend was observed for leaf Mn, although it increased only in the biochar amended soil 313 (Table 5).

314 Independently of the fertilization strategy, biochar induced an increase in leaf K and a 315 reduction in leaf $\mathrm{Ca}$ concentration (Table 5), while no effects were observed on leaf $\mathrm{N}$, $316 \mathrm{P}, \mathrm{Cu}$ and $\mathrm{Zn}$ concentration (Table 4).

\subsubsection{Soil pH and soil extractable micronutrients}

Soil $\mathrm{pH}$ was significantly higher in soil amended with biochar (7.56 vs. 7.45$)$ without interaction between biochar and fertilization strategies (Table 6). Among strategies, soil $\mathrm{pH}$ was reduced in soils fertilized with Fe chelate, A. retroflexus $+\mathrm{FeSO}_{4}$ and siderite with comparable values among them (Table 6).

Fertilization strategies significantly affected soil extractable micronutrients. Soil extractable $\mathrm{Fe}$ was increased only by synthetic Fe treatment when $\mathrm{DI}-\mathrm{H}_{2} \mathrm{O}$ was used as eluent (Table 6), while with DTPA, the A. retroflexus $+\mathrm{FeSO}_{4}$ induced the highest value, followed by siderite (Table 6). The latter increased DTPA-extractable Fe compared to soils untreated and fertigated with the vegetal extract alone, while intermediate values were obtained by Fe-chelate (Table 6). Compared to other strategies, soil DTPA-extractable $\mathrm{Cu}$ was reduced by Fe-chelate application whereas soil DTPA extractable Mn and Zn were not affected by fertilization treatments (Table $6)$.

332 Soil amended with biochar significantly decreased the amount of Fe extracted by DI$\mathrm{H}_{2} \mathrm{O}$ while an opposite trend emerged using DTPA as extractor agent (Table 6). A similar response was also measured for soil DTPA extractable $\mathrm{Mn}, \mathrm{Cu}$ and $\mathrm{Zn}$ concentration, without interaction with fertilization strategies (Table 6). 


\subsection{Biochar micronutrients release and retention potential}

338

The amount of $\mathrm{Fe}, \mathrm{Mn}, \mathrm{Cu}$ and $\mathrm{Zn}$ released by biochar in $\mathrm{DI}-\mathrm{H}_{2} \mathrm{O}$ was negligible, independent of the application rate (data not shown). Values of these metals in solution were lower than $0.015 \mathrm{mg} \mathrm{L}^{-1}$ on average (comparable to those of pure DI- $\mathrm{H}_{2} \mathrm{O}$ ). Therefore, biochar application rate and released micronutrient concentration were not significantly linked (data not shown).

Conversely, when biochar was soaked in $10 \mathrm{mg} \mathrm{L}^{-1}$ solutions of $\mathrm{Fe}, \mathrm{Mn}, \mathrm{Cu}$ and $\mathrm{Zn}$ (separately), it significantly reduced the amount of cations in solution as the biochar rate increased (Fig. 2). A significant negative relationship emerged between the concentration of dissolved Fe after the addition of biochar and biochar rate, which best fitted with a polynomial trend $\left(r^{2}=0.92\right)$ (Fig. 2). Similarly, $\mathrm{Mn}, \mathrm{Cu}$ and $\mathrm{Zn}$ concentrations were negatively and linearly linked with biochar rate and $r^{2}$ values were 0.93, 0.93 and 0.88 , respectively (Fig. 2).

\subsection{Biochar surface chemistry change as affected by exposure to Fe metal}

After exposure to $\mathrm{Fe}$, biochar fragments showed diffuse rusty spots distributed over their surface (Fig. 3). The surface relative atomic concentration (at \%), as measured by XPS, was $14.9 \pm 2.14,65 \pm 5.21$ and $22.6 \pm 7.36$ (avg. \pm SE $n=3$ ) for Fe, $\mathrm{O}$ and $\mathrm{C}$, respectively. On the contrary, the biochar surface was not visibly altered in colour after it had been dipped 1 week in DI- $\mathrm{H}_{2} \mathrm{O}$, and its surface atomic concentration was $0.12 \pm 0.002,14.2 \pm 1.62$ and $86.1 \pm 2.60$ (at\%, avg. $\pm \mathrm{SE} \mathrm{n}=3$ ) for $\mathrm{Fe}, \mathrm{O}$ and $\mathrm{C}$ respectively. 


\section{DISCUSSION}

361

362

\subsection{Biochar hinders kiwifruit Fe nutrition}

There are three mechanisms potentially responsible for the negative impact of biochar on plant Fe and Mn uptake: i) a biochar-driven $\mathrm{pH}$ increase, which would cause a reduction in the ability of the Fe $\mathrm{e}^{\mathrm{III}}$ chelate reductase enzyme to transport Fe to cells, ii) ionic bonding of $\mathrm{Fe}$ and $\mathrm{Mn}$ to oxidized groups on the biochar surface, and iii) a redoxdriven precipitation of iron oxides on the surface of biochar particles, which would pull any available Fe out of solution. The first mechanism, a soil $\mathrm{pH}$ increase, is unlikely to have driven the entire negative impact of biochar on plant Fe and Mn uptake because the observed $\mathrm{pH}$ shift was less than 0.1 units. Although we cannot completely rule out a role for this small $\mathrm{pH}$ shift, extraction data, microscopic images, and XPS data point to a major role for mechanisms that hold $\mathrm{Fe}$ and Mn more tightly to the biochar surface.

Chemical extraction data suggest that biochar-amended soils held Fe much more effectively (Table 6). DI- $\mathrm{H}_{2} \mathrm{O}$ extraction (a measure of weakly held $\mathrm{Fe}$ ) extracted $57 \%$ less Fe into solution from soils amended with biochar compared to unamended soils (Table 6). On the other hand, a stronger extractant (DTPA) removed more Fe from the biochar-amended soil than the control soil, with the difference reflecting the balance not removed by the first extraction (Table 6). We observed a similar trend for the other micronutrients, suggesting that biochar retained Fe from the soil solution (as well as other cations) and a weak eluent, such as DI- $\mathrm{H}_{2} \mathrm{O}$, was ineffective in solubilizing it. Others have observed a reduction of soil Mn availability upon the addition of biochar to soils (Alling et al., 2014). Although the DI- $\mathrm{H}_{2} \mathrm{O}$ and DTPA extractions did not allow us to separate out the relative importance of ionic bonding from redox-driven precipitation reactions, microscopic images show the formation of precipitated Fe oxides on the 
surface, making it clear that this third process was active. Therefore, we hypothesize that in potted conditions Fe in soil solution was attracted and retained by biochar (as observed in the second experiment), thereby limiting its availability (in particular in the first season) for plant uptake, accentuating Fe-chlorosis symptoms of kiwifruit vines. After the first season, symptoms of Fe-chlorosis in biochar-amended vines were less evident, suggesting that one growing season was sufficient to saturate the biochar surface. This may be because the surface became loaded with cations or because a sort of cation exchange equilibrium was reached, leading to an increase of $\mathrm{Fe}$ availability for plant uptake over time. The fact that Fe was attracted by biochar in soil has been reported also by Lin et al. (2012) who, using transmission electron microscopy (TEM) equipped with energy dispersive spectroscopy (EDS) for elemental analysis, showed that the mineral matter attached to the biochar surfaces on fragments recovered after a 3-month soil incubation experiment included higher concentration of elements such as $\mathrm{O}, \mathrm{Al}, \mathrm{Si}, \mathrm{Fe}, \mathrm{Ti}$ and trace amounts of other elements such as $\mathrm{Mn}, \mathrm{Mg}, \mathrm{Ca}, \mathrm{K}, \mathrm{Na}, \mathrm{P}$, and S compared to fresh biochars.

\subsection{Micronutrient release from biochar is negligible}

401

In our conditions, biochar did not affect $\mathrm{Fe}, \mathrm{Mn}, \mathrm{Cu}$ and $\mathrm{Zn}$ concentration in solution independent of the rate of biochar application (data are available in Fig. S1 of the supplementary material). This response was expected and could be ascribed to: i) the poor micronutrient content in the hardwood feedstock; ii) the scarcity of ash (since biochar was repeatedly washed prior testing) and iii) the retention of micronutrients (i.e. Fe and Mn) in biochar (Amonette and Joseph 2009), thereby transforming them into less soluble chemical forms (Wang et al., 2009), confirming the poor value of biochars 
as a direct source of micronutrients (Novak et al., 2009). Although it has been suggested that biochar may represent a potential source of macro- and micronutrients for plants and the soil microbial community (Downie et al., 2009), direct nutrient supply by biochar is often negligible, in particular when plant biomass is used as feedstock (Gaskin et al., 2008; Singh et al., 2010), as it was here. However, since our results were obtained by testing one specific biochar, we cannot exclude that others biochars behave differently.

\subsection{Biochar acts as a retaining additive for micronutrients in soil}

In our lab experiments, the biochar used in this trial showed a high retention affinity for micronutrients when they were available in solution (Fig. 2). In fact, increasing rates of biochar (and thereby total surface area), progressively reduced the initial content of all micronutrients in solution, suggesting that biochar attracted and retained all the cations we tested (Fig. 2). This phenomenon is consistent with the work of others (e.g. Novak et al., 2009). The affinity of biochar for micronutrients occurred in the order $\mathrm{Fe}>\mathrm{Cu}>\mathrm{Zn}>\mathrm{Mn}$. Biochar completely removed Fe in solution $\left(10 \mathrm{mg} \mathrm{L}^{-1}\right)$ between 20 and $30 \mathrm{~g} \mathrm{~L}^{-1}$ while more biochar was required to completely strip $\mathrm{Cu}$ from solution (between 30 and $40 \mathrm{~g} \mathrm{~L}^{-1}$ ). The highest biochar concentrations in our solution experiments were insufficient to remove all the $\mathrm{Zn}$ and $\mathrm{Mn}$ from solution, with $\sim 80 \%$ of 427 the $\mathrm{Zn}$ and $\sim 50 \%$ of the Mn removed at the highest biochar rate $\left(40 \mathrm{~g} \mathrm{~L}^{-1}\right)$ (Fig. 2).

428 The ability of biochar to sorb and desorb cations and anions has been ascribed to its cation exchange capacity (CEC) and anion exchange capacity (AEC) (Liang et al., 2006). 
431 The chemical interaction of biochar with elements dissolved in solution has been

432 attributed to a range of functional groups identified on its surface, including hydroxyl (-

$433 \mathrm{OH})$, carbonyl $(-\mathrm{C}=\mathrm{O})$, carboxylate $(-\mathrm{COOH})$, hydrogen $(\mathrm{H})$ and ether $(\mathrm{R}-\mathrm{O}-\mathrm{R})(\mathrm{Cheng}$

434 et al., 2008; Mao et al., 2012). Negatively charged carboxyl groups on the biochar

435 surface, whose presence is estimated by the high O:C ratios, are mainly responsible for

436 the high CEC of most biochars (Chan and Xu 2009), since other groups are mostly polar

437 and uncharged (i.e. hydroxyl, carbonyl). However, even uncharged functional groups on

438 the biochar surface contribute to cation retention by cation- $\pi$ bonding mechanisms

439 (Harvey et al., 2011). This structure allows the sorption of molecules with both polar

440 and non-polar portions on the biochar surface.

441 The ability of our biochar to retain cations could have been accentuated by the fact that

442 it was 4 years old. In fact, it has been suggested that the CEC of biochar increases with

443 biochar ages as shown by high concentrations of negative charges on the biochar

444 surface due to surface oxidation induced by abiotic processes (Cheng et al., 2006), while

445 AEC is likely to be reduced.

446 It is also possible that the observed cation retention was due in part to the physical

447 structure of biochar. Its high surface area and porosity likely increased the contact

448 between biochar particles and solution (Major et al., 2009). The nutrient sorption might

449 partly result from dissolved nutrients physically held in the porous structure of biochar

450 before drying and analysis. However, it is unlikely that water absorption completely

451 explains the observed differences since it is doubtful that $100 \%$ of the $\mathrm{Fe}$ and $\mathrm{Cu}$ in

452 solution were physically trapped into biochar pores.

453

$454 \quad 4.4$ Fe exposure induces a redox reaction at the biochar surface level 
455 Recently, it has been demonstrated that since biochar is redox-active (Klüpfel et al., 456 2014; Saquing et al., 2016), it can be involved in abiotic redox reactions (Oh et al., 457 2013) and, depending on the feedstock and charring temperature, biochar can accept and 458 donate several hundred micromoles of electrons per gram (Klüpfel et al., 2014).

459 Moreover, results from Kappler et al. (2014) suggest that biochar in soil can alter soil biogeochemistry either indirectly by changing the soil structure and chemistry or directly by mediating electron transfer processes, by functioning as an electron shuttle. In our experiment, biochar clearly showed diffuse rusty spots on its surface after exposure to Fe (Fig. 3), and the relative surface atomic concentration significantly changed for $\mathrm{Fe}, \mathrm{O}$ and $\mathrm{C}$. The relative $\mathrm{O}$ and $\mathrm{Fe}$ concentration of the biochar surface was much higher than in control fragments, suggesting that Fe was oxidized on the biochar surface. Because Fe metal particles (used as a source of Fe) were larger in size $(>350 \mu \mathrm{m})$ than biochar pores (mostly $<100 \mu \mathrm{m})$, it is unlikely that they were physically trapped on the biochar surface. XPS data point to the growth of a $\mathrm{Fe}_{2} \mathrm{O}_{3}$ film on the surface of the biochar particles. The Fe:O stoichiometric ratio changed from a value that was extremely low (0.00085) to a value of 0.659 after exposure the Fe in the lab, very close to the expected value of 0.667 for pure $\mathrm{Fe}_{2} \mathrm{O}_{3}$. Although this evidence shows that the biochar interacted with $\mathrm{Fe}$, we cannot exclude the

474 formation of $\mathrm{Fe}(\mathrm{OH})_{3}$ as an intermediate product or that that $\mathrm{Fe}$ simply dissolved into 475 the water precipitated as $\mathrm{Fe}_{2} \mathrm{O}_{3}$ onto the biochar surface.

476 This evidence helps explain at least one mechanism that occurred in the potted 477 experiment, and consequently helps explains plant responses. Although other reactions cannot be excluded, we hypothesize that Fe interacted with the biochar and a redox 
479 reaction occurred on its surface. The Fe source was the reducing agent (donor of 480 electrons) while water was the oxidizing agent (acceptor of electrons). This process may 481 have been promoted by the presence of biochar functioning as an electron transfer 482 mediator (Klüpfel et al., 2014). The reduction step released $\mathrm{Fe}^{2+}$ in solution that was 483 electrostatically attracted to the biochar surface (Kappler et al., 2014) by reactive carboxylic and phenolic functional groups (Lin et al., 2012) and then oxidized. The redox reaction can be summarized as follows:

$\mathrm{Fe} \rightarrow \mathrm{Fe}^{2+}+2 \mathrm{e}^{-} \rightarrow \mathrm{Fe}^{3+}+1 \mathrm{e}^{-}$(oxidation)

$\mathrm{O}_{2}+4 \mathrm{e}^{-}+2 \mathrm{H}_{2} \mathrm{O} \rightarrow 4 \mathrm{OH}^{-}$(reduction)

488 the product of such reaction was:

$4 \mathrm{Fe}+3 \mathrm{O}_{2}+6 \mathrm{H}_{2} \mathrm{O} \rightarrow 4 \mathrm{Fe}(\mathrm{OH})_{3}$

Then, the ferric hydroxide $\left(\mathrm{Fe}(\mathrm{OH})_{3}\right)$ precipitated as hydrated ferric oxides, resulting in rust as final product observed on the biochar surface:

$2 \mathrm{Fe}(\mathrm{OH})_{3} \rightarrow \mathrm{Fe}_{2} \mathrm{O}_{3} \cdot 3 \mathrm{H}_{2} \mathrm{O}$

\subsection{Sustainable strategies were effective in preventing Fe-chlorosis}

Leaf Fe-chlorosis symptoms (interveinal yellowing starting from youngest leaves) were effectively prevented in both seasons by soil-applied Fe-chelate (the current standard approach), which induced the highest SPAD (data are available in Table S1 and S2 of the supplementary material) values (but see below for negative Mn response). Symptoms in the first year were prevented to a similar extent by the A. retroflexus aqueous extract when enriched with $\mathrm{FeSO}_{4}$ (but not when applied alone) and siderite, while the latter two treatments were slightly less effective the following year (data are available in Table S1 and S2 of the supplementary material). Untreated and plants 
treated with $A$. retroflexus aqueous extract alone died as a consequence of the persistent

504 Fe deficiency induced by the prohibitive growing conditions, confirming the high susceptibility of kiwifruit plants to this disorder and the severe consequences of

506 prolonged Fe-chlorosis.

507 The beneficial effect on Fe nutrition induced by A. retroflexus aqueous extract is likely attributable to the chelating compounds (e.g. organic acids, amino acids, bioregulatorlike substances, and siderophores) released by the A. retroflexus spp. tissues during either maceration or soil-incorporation (Goos et al., 2001; Matocha and Pennington, 1982; Matocha, 1984; Mostaghimi and Matocha, 1988) which were able to increase Feavailability in soil. In fact, Sorrenti et al. (2011) measured a 100-fold higher concentration of solubilized Fe from a similar calcareous soil using the aqueous vegetal extract of A. retroflexus as Fe-extractant compared to $\mathrm{DI}-\mathrm{H}_{2} \mathrm{O}$.

However, in our conditions the A. retroflexus aqueous extract alone did not improve Fe nutrition. This may be because the amount of solubilized Fe from a soil naturally poor in Fe was insufficient to sustain plant Fe requirements, while it was enough when the aqueous extract was enriched with an exogenous source of Fe which promoted a weak linkage between $\mathrm{Fe}$ and the organic compounds released by the A. retroflexus tissues. A similar response was observed in field conditions (Sorrenti et al., 2011), where Fe nutrition of pear trees was improved by the vegetal extract but only when enriched with

$522 \mathrm{FeSO}_{4}$, suggesting a beneficial effect of the $A$. retroflexus as a natural chelator and its 523 affinity for $\mathrm{Fe}$.

524 Siderite has been proposed as a long-term slow-release Fe fertilizer able to prevent $\mathrm{Fe}$ chlorosis symptoms in olive trees (Sánchez-Alcalá et al., 2012a). The effectiveness of siderite, as also described for synthetic vivianite, is related to its oxidation in calcareous 
media resulting in the production of poorly crystalline lepidocrocite and/or goethite

528 (Sánchez-Alcalá et al., 2012b) that, as with other poorly crystalline of nanometer-size

529 Fe-oxides, represent a significant source of Fe for plants (de Santiago and Delgado

530 2006; Sánchez-Alcalá et al., 2012b). However, the application of siderite (only once at

531 the beginning of the experiment) was more effective in the first than in the second season, suggesting that its effectiveness may not last as long as suggested previously

533 (Sánchez-Alcalá et al., 2012a and literature therein).

534 The increased leaf $\mathrm{K}$ concentration observed in plants treated with siderite and vegetal extract of A. retroflexus (Table 5) could be a consequence of the direct supply of this nutrient by siderite (obtained by mixing $\mathrm{KCO}_{3}$ and $\mathrm{FeSO}_{4}$ ), while the vegetal extract may have a possible positive effect also on extracting this macronutrient from soil. A similar increase in leaf $\mathrm{K}$ concentration was observed in pear trees fertigated with $A$. retroflexus aqueous extract (Sorrenti et al., 2011).

540 In agreement with literature, Fe-chelate treatments dramatically decreased leaf Mn 541 concentration (Table 5) because of the competitive effect of these synthetic molecules on Mn uptake, as shown in herbaceous as well as in perennial species (Ghasemi Fasaei et al., 2003; Sorrenti et al., 2011; Wallace and Alexander ,1973). These results suggest that to avoid Mn deficiency, supplementary applications of this micronutrient to the canopy should be considered in commercial orchards when Fe-chelates are repeatedly 546 used.

\section{CONCLUSION}

549 Although we investigated one specific biochar, in our conditions hardwood derived biochar showed a high potential to remove $\mathrm{Fe}, \mathrm{Mn}, \mathrm{Cu}$ and $\mathrm{Zn}$ in solution, likely 
551 through reactive functional groups on its surface while it showed little value as a source

552 of these micronutrients. The affinity of biochar for cations, together with its ability to

553 accept and donate electrons, could trigger redox reactions in soil with significant

554 implications for micronutrient biogeochemical cycling thereby also affecting nutrient

555 forms and availability for plants. In our conditions, the synergic occurrence of these

556 processes in biochar-amended soil, sequestered part of the available micronutrients,

557 limiting their availability for plant uptake.

558 Incorporating biochar in Fe-limited growing environments (i.e. alkaline-calcareous

559 soils) hindered plant Fe nutrition, and as a consequence worsened the Fe-chlorosis

560 incidence on kiwifruit vines, especially in the first season. This example of biochar-soil

561 interactions must be taken into consideration in the use of biochar as an amendment.

562 Similarly, adequate countermeasures need to be evaluated (e.g. pre-treatment of biochar

563 with $\mathrm{Fe}$ ). However, given that biochar-induced effects may change with application

564 rates, studies with lower rates compared to that adopted in this study $\left(5 \mathrm{~g} \mathrm{~kg}^{-1} \mathrm{~W} \mathrm{w}^{-1}\right)$

565 could elucidate the real impact of this strategy. Likewise, studies are needed to confirm

566 this effect in different soils and determine how aging will affect these properties of

567 biochar.

568 Finally, our results indicate the potential of innovative and sustainable strategies

569 (aqueous extract of $A$. retroflexus enriched with $\mathrm{FeSO}_{4}$ and siderite) to alleviate

570 symptoms of Fe chlorosis of kiwifruit vines grown in heavy calcareous soil. These

571 techniques may be improvements on the current standard approach (application of Fe-

572 chelates), which poses plant nutritional and potential environmental challenges. 


\section{ACKNOWLEDGMENTS}

575 The authors thank Dr. Bo Chen for is valuable assistance with XPS analyses and Dr.

576 Yousif Shamoo for providing microscope access. We also acknowledge funding from

577 the US NSF through grant EAR 0911685. Authors thank three anonymous reviews for

578 their valuable comments which helped to improve the manuscript.

579

$580 \quad 7 . \quad$ REFERENCES

581 Abadía, J., Abadía, A., 1993. Iron and plant pigments, in: Barton, L.L., Hemming, B.C.,

582 (Eds.), Iron Chelation in Plants and Soil Microorganisms. Academic Press, New York, 583 pp. 327-343.

584

585 Abadía, J., Vázquez, S., Rellán-Álvarez, R., El-Jendoubi, H., Abadía, A., Álvarez-

586 Fernández, A., López-Millán, A.F., 2011. Towards a knowledge-based correction of 587 iron chlorosis. Plant Physiol. Biochem. 49, 471-482.

588

589 Alling, V., Hale, S.E., Martinsen, V., Mulder, J., Smebye, A., Breedveld, G.D.,

590 Cornelissen, G., 2014. The role of biochar in retaining nutrients in amended tropical 591 soils. J. Soil Sci. Plant Nutr. 177(5), 671-680.

592

593 Álvarez-Fernández, A., Abadía, J., Abadía, A., 2006. Iron deficiency, fruit yield and 594 fruit quality, in: Barton, L.L., Abadía, J. (Eds.), Iron Nutrition in Plants and 595 Rhizospheric Microorganisms. Springer, Dordrecht, Netherlands, pp. 85-101. 596 
597

598

599

600

601

602

603

604

605

606

607

608

609

610

611

612

613

614

615

616

617

618

619

620

Amonette, J.E., Joseph, S., 2009. Characteristics of biochar: Microchemical properties, in: Lehmann, J., Joseph, S. (Eds.), Biochar for environmental management: science and technology. Earthscan, London, UK, pp. 33-52.

Atkinson, C.J., Fitzgerald, J.D., Hipps, N.A., 2010. Potential mechanisms for achieving agricultural benefits from biochar application to temperate soils: a review. Plant Soil. 337(1-2), 1-18.

Baronti, S., Vaccari, F.P., Miglietta, F., Calzolari, C., Lugato, E., Orlandini, S., Genesio, L., 2014. Impact of biochar application on plant water relations in Vitis vinifera (L). Eur. J. of Agron. 53, 38-44.

Bingham, F.T. 1982. Boron, in: Page, A.L. Miller, R.H., Keeney, D.R. (Eds.), Methods of Soil Analysis. Part 2: Chemical and Microbiological Properties. $2^{\text {nd }}$ ed. Agronomy No. 9. American Society of America, Madison, WI, pp. 431-436.

Cañasveras, J.C., Sánchez-Rodríguez, A.R., del Campillo, M.C., Barrón, V., Torrent, J., 2014. Lowering iron chlorosis of olive by soil application of iron sulfate or siderite. Agron. Sustain. Dev. 34(3), 677-684.

Çelik, H., Katkat, A.V., 2010. Comparison of Various Chemical Extraction Methods used for Determination of the Available Iron Amounts of Calcareous Soils. Commun. Soil Sci. Plant Anal. 41(3), 290-300. 
621 Chan, K.Y., Xu, Z., 2009. Biochar: nutrient properties and their enhancement, in:

622 Lehmann, J., Joseph, S. (Eds.), Biochar for environmental management: science and 623 technology. Earthscan, London, UK, pp. 67-84.

624

625 Cheng, C.H., Lehmann, J., Thies, J.E., Burton, S.D., Engelhard, M.H., 2006. Oxidation 626 of black carbon by biotic and abiotic processes. Org. Geochem. 37, 1477-1488.

627

628

Cheng, C.H., Lehmann, J., Engelhard, M.H., 2008. Natural oxidation of black carbon in 629 soils: Changes in molecular form and surface charge along a climosequence. Geochim. 630 Cosmochim. Acta 72, 1598-1610.

631

632 de Santiago, A., Delgado, A., 2006. Predicting iron chlorosis of Lupinus albus L in 633 calcareous Spanish soils from various iron extracts. Soil Sci. Soc. Am. J. 70, 19451950.

635

Downie, A., Crosky, A., Munroe, P., 2009. Physical properties of biochar, in: Lehmann, 637 J., Joseph, S. (Eds.), Biochar for environmental management: science and technology. 638 Earthscan, London, UK, pp.13-32.

639

640 Drouineau, G., 1942. Dosage rapide du calcaire actif du sol: Nouvelles données sur la 641 separation et la nature des fractions calcaires. Ann. Agron, 12, 441-450.

642

643 Eichert, T., Peguero-Pina, J.J., Gil-Pelegrín, E., Heredia, A., Fernández, V., 2010.

644 Effects of iron chlorosis and iron resupply on leaf xylem architecture, water relations, 
gas exchange and stomatal performance of field-grown peach (Prunus persica). Physiol. Plant. 138, 48-59.

647

648 Fernández, V., Eichert, T., Del Río, V., López-Casado, G., Heredia-Guerrero, J.A, 649 Abadía, A., Heredia, A., Abadía, J., 2008. Leaf structural changes associated with iron 650 deficiency chlorosis in field-grown pear and peach: physiological implications. Plant 651 Soil, 311, 161-172.

652

653 Gaskin, J.W., Steiner, C., Harris, K., Das, K.C., Bibens, B., 2008. Effect of low654 temperature pyrolysis conditions on biochar for agricultural use. Trans. Asabe 51, 20616552069.

656

657 Ghasemi Fasaei, R., Ronaghi, A., Maftoun, M., Karimian, N., Soltanpour, PN., 2003. 658 Influence of Fe-EDDHA on iron manganese interaction in soybean genotypes in a 659 calcareous soil. J. Plant Nutr. 26(9), 1815-1823.

660

661 Goos, R.J., Johnson, B.E., Peterson, R.A., Kobes, N., 2001. Effect of sugarbeet by662 products on the solubility and availability of ferrous sulfate in soil. J. Sugar Beet Res. $66338(2), 153-172$.

664

665 Graber, E.R., Tsechansky, L., Lew, B., Cohen, E., 2014. Reducing capacity of water 666 extracts of biochars and their solubilization of soil Mn and Fe. Eur. J Soil Sci, 65(1), 667 $162-172$.

668 
669 Grčman, H., Velikoja-Bolta, Š., Vodnik, D., Kos, B., Leštan, D., 2001. EDTA enhanced 670 heavy metal phytoextraction: metal accumulation, leaching and toxicity. Plant Soil. 235, $671 \quad 105-114$.

672

673 Harvey, O.R., Herbert, B.E., Rhue, R.D., Kuo, L.J., 2011. Metal interactions at the 674 biochar-water interface: energetics and structure-sorption relationships elucidated by 675 flow adsorption microcalorimetry. Environ. Sci. Technol., 45(13), 5550-5556.

676

677 Hendershot, W.H., Duquette, M., 1986. A simple barium chloride method for 678 determining cation exchange capacity and exchangeable cations. Soil Sci. Soc. Am.

679 J., 50(3), 605-608.

680

Jeffery, S., Verheijen, F.G.A., Van Der Velde, M., Bastos, A.C., 2011. A quantitative review of the effects of biochar application to soils on crop productivity using metaanalysis. Agr. Ecosyst. Environ. 144(1), 175-187.

684

685

Joseph, S.D., Camps-Arbestain, M., Lin, Y., Munroe, P., Chia, C.H., Hook, J., van 686

Zwieten, L., Kimber, S., Cowie, A., Singh, B.P., Lehmann, J., Foidl, N., Smernik, R.J.,

Amonette, J.E., 2010. An investigation into the reactions of biochar in soil. Soil

Research, 48(7), 501-515.

689

690

Joseph, S., Husson, O., Graber, E. R., Van Zwieten, L., Taherymoosavi, S., Thomas, T., 691 Nielsen, S., Ye, J., Pan, G., Chia, C., Munroe, P., Allen, J., Lin, Y., Fan, X., Donne, S., 692 2015. The Electrochemical Properties of Biochars and How They Affect Soil Redox Properties and Processes. Agronomy, 5(3), 322-340. 
Kappler, A., Wuestner, M.L., Ruecker, A., Harter, J., Halama, M., Behrens, S., 2014.

696

Biochar as electron shuttle between bacteria and Fe (III) minerals. Environ. Sci.

697

Technol. Letters. 1(8), 339-344.

698

699

Kingston, H.M., 1988. EPA IAG DWI-393254-01-0 January 1-March 31, Quarterly

700

Report, 1988 Washington, DC: EPA.

701

702

Klüpfel, L., Keiluweit, M., Kleber, M., Sander, M., 2014. Redox properties of plant

703

biomass-derived black carbon (biochar). Environ. Sci. Technol. 48, 5601-5611.

704

705

Laird, D.A., 2008. The charcoal vision: a win-win-win scenario for simultaneously

706

producing bioenergy, permanently sequestering carbon, while improving soil and water

707 quality. Agron. J., 100(1), 178-181.

708

709

LeCroy, C., Masiello, C.A., Rudgers, J.A., Hockaday, W.C., Silberg, J.J., 2013.

710

Nitrogen, biochar, and mycorrhizae: Alteration of the symbiosis and oxidation of the

711 char surface. Soil Biol. Biochem. 58, 248-254.

712

713

Lehmann, J., 2007. Bio-energy in the black. Front. Ecol. Environ. 5(7), 381-387.

714

715 Liang, B., Lehmann, J., Solomon, D., Kinyangi, J., Grossman, J., O'neill, B., Neves,

716 E.G., 2006. Black carbon increases cation exchange capacity in soils. Soil Sci. Soc. Am.

717

J. 70(5), 1719-1730. 
719 Lin, Y., Munroe, P., Joseph, S., Kimber, S., Van Zwieten, L., 2012. Nanoscale organo720 mineral reactions of biochars in ferrosol: an investigation using microscopy. Plant 721 Soil, 357(1-2), 369-380.

722

723 Lindsay, W.L., Norvell, W.A., 1978. Development of a DTPA soil test for zinc, iron, 724 manganese and copper. Soil Sci. Soc. Am. J. 42, 421-428.

725

726

Lucena, J.J., 2006. Synthetic iron chelates to correct iron deficiency in plants, in:

Barton, L.L., Abadía, J. (Eds.), Iron Nutrition in Plants and Rhizospheric

Microorganisms. Springer, Dordrecht, Netherlands, pp. 103-128.

729

730

Major, J., Steiner, C., Downie, A., Lehmann, J., 2009. Biochar effects on nutrient

731 leaching, in: Lehmann, J., Joseph, S. (Eds.), Biochar for environmental management: 732 science and technology. Earthscan, London, UK, pp. 271-288.

733

734

Mao, J.D., Johnson, R.L., Lehmann, J., Olk, D.C., Neves, E.G., Thompson, M.L.,

735

Schmidt-Rohr, K., 2012. Abundant and stable char residues in soils: implications for soil fertility and carbon sequestration. Environ. Sci. Technol. 46(17), 9571-9576.

737

Matocha, J.E., Pennington, D., 1982. Effects of plant iron recycling on iron chlorosis of 739 grain sorghum on calcareous soils. J. Plant Nutr. 5(4-7), 869-882. 
753

754

755

756

757

758

759

760

761

762

763

Matocha, J.E., 1984. Grain sorghum response to plant residue-recycled iron and other iron sources. J. Plant Nutr. 7(1-5), 259-270.

Mostaghimi, S., Matocha, J.E., 1988. Effects of normal and Fe-treated organic matter on Fe chlorosis and yields of grain sorghum. Commun. Soil Sci. Plant Anal. 19(13), 14151428.

Nörtemann, B., 1999. Biodegradation of EDTA. Appl. Microbiol. Biot. 51(6), 751-759.

Novak, J.M., Busscher, W.J., Laird, D.L., Ahmedna, M., Watts, D.W., Niandou, M.A., 2009. Impact of biochar amendment on fertility of a south eastern coastal plain soil. Soil Sci. 174(2), 105-112.

Oh, S.Y., Son, J.G., Chiu, P.C., 2013. Biochar-mediated reductive transformation of nitro herbicides and explosives. Environ, Toxicol, Chem, 32, 501-508.

Olsen, S.R., Sommers, L.E., 1982. Phosphorus, in: Page, A.L., Miller, R.H., Keeney, D.R. (Eds.), Methods of Soil Analysis, Part 2, 2nd edn, Agron. Monogr 9. ASA and ASSA, Madison WI, pp. 403-430.

Pestana, M., de Verennes, A., Araujo Faria, E., 2003. Diagnosis and correction of iron chlorosis in fruit trees: a review. J. Food Agric. Environ. 1(1), 46-51. 
781

782

Roldán, R., Barrón, V., Torrent J., 2002. Experimental alteration of vivianite to lepidocrocite in a calcareous medium. Clay Miner. 37, 709-718.

Römheld, V., Marschner, H., 1986. Evidence for a specific uptake system for iron phytosiderophores in roots of grasses. Plant Physiol. 80, 175-180.

Römheld, V., Nikolic, M., 2007. Iron, in: Barker, A.V., Pilbeam, D.J., (Eds.), Handbook of plant nutrition. CRC Press, Taylor and Francis, Group Boca Raton, FL, USA, pp. 329-350.

Rosado, R., del Campillo, M.C., Martínez MA, Barrón V, Torrent J., 2002. Long-term effectiveness of vivianite in reducing iron chlorosis in olive trees. Plant Soil, 241(1), $139-144$.

Sánchez-Alcalá, I., del Campillo, M.C., Barrón, V., Torrent, J., 2012a. Pot evaluation of synthetic nanosiderite for the prevention of iron chlorosis. J. Sci. Food Agr. 92, 19641973.

Sánchez-Alcalá, I., Bellón, F., del Campillo, M.C., Barrón, V., Torrent, J., 2012b. Application of synthetic siderite $\left(\mathrm{FeCO}_{3}\right)$ to the soil is capable of alleviating iron chlorosis in olive trees. Sci. Hortic. 138, 17-23. 
Saquing, J., Yu, Y-H., Chiu, P., 2016. Wood-Derived Black Carbon (Biochar) as a Microbial Electron Donor and Acceptor. Environmental Science \& Technology Letters. acs.estlett.5b00354. http://doi.org/10.1021/acs.estlett.5b00354

Saunders, W.M,. Williams, E.G., 1955. Observations of the determinations of organic phosphorus in soils. J. Soil Sci. 6,254-267.

Saville, D.J., Rowarth J.S., 2008. Statistical measures, hypotheses, and tests in applied research. J. Nat. Resour. Life Sci. Educ. 37, 74-82.

Schuman, G.E., Stanley, A.M., Knudsen, D., 1973. Automated total nitrogen analysis of soil and plant samples. Soil Sci. Soc. Am. J. 37, 480-481.

Singh, B.P, Hatton, B.J, Singh, B., Cowie, A., Kathuria, A., 2010. Influence of biochars on nitrous oxide emission and nitrogen leaching from two contrasting soils. J. Environ. Qual. 39, 1224-1235.

Soltanpour, P.A., Schwab, A.P., 1977. A new soil test for simultaneous extraction of macro and micro nutrients in alkaline soils 1. Commun. Soil Sci. Plan., 8(3), 195-207.

Soltner, D., 1988. Le bases de la production vegetale. Tome 1: Le sol (sixteenth ed.), Collection Sciences et Tecniques Agricoles, Angers 

Sci. Plant Nutr. 57(6), 813-822.

812

813 Sorrenti, G., Toselli, M., Marangoni, B., 2012. Use of compost to manage Fe nutrition of pear trees grown in calcareous soil. Sci. Hortic. 136, 87-94.

815

Susin, S., Abadía, A., González-Reyes, J.A., Lucena J.J., Abadía, J., 1996. The pH requirement for in vivo activity of the iron-deficiency-induced "Turbo" ferric chelate reductase (a comparison of the iron-deficiency-induced iron reductase activities of intact plants and isolated plasma membrane fractions in sugar beet). Plant Physiol. 110(1), 111-123.

821

Tagliavini, M., Abadía, J., Rombolà, A.D., Tsipouridis, C., Marangoni, B., 2000. Agronomic means for the control of iron deficiency chlorosis in deciduous fruit trees. J. Plant Nutr. 23(11-12), 2007-2022.

825

826

Tagliavini, M., Rombolà, A.D., 2001. Iron deficiency and chlorosis in orchard and vineyard ecosystems: a review. Eur J. Agron. 15, 71-92.

Wallace, A., Alexander, G.V., 1973. Manganese in plants as influenced by manganese and iron chelates. Commun. Soil Sci. Plan. 4(1), 51-56. 
832 Wang, N., Li, J.Y., Xu, R.K., 2009. Use of various agricultural by-products to study the $833 \mathrm{pH}$ effects in an acid tea garden soil. Soil Use Manage. 25, 128-132. 
1 Table 1. Selected chemical and physical characteristics of the soil used in the experiment

\begin{tabular}{|c|c|c|c|}
\hline Parameter & Value & Unit & Extractant/method \\
\hline \multicolumn{4}{|l|}{ Texture } \\
\hline Sand & 24 & $\%$ & \\
\hline Silt & 53 & $\%$ & \\
\hline Clay & 23 & $\%$ & \\
\hline Total carbonate $\left(\mathrm{CaCO}_{3}\right)$ & 78 & $\%$ & $\mathrm{HCl} / \mathrm{De}$ Astis method \\
\hline Active lime $\left(\mathrm{CaCO}_{3}\right)$ & 19.2 & $\%$ & Ammonium oxalate (Drouineau, 1942) \\
\hline Organic matter & 0.54 & $\%$ & Walkley-Black 1919 (Soltner, 1988) \\
\hline Total N & 0.39 & $\%$ & Kjeldahl method \\
\hline Available phosphorus (P) & 3 & $\mathrm{mg} \mathrm{kg}^{-1}$ & Olsen (Olsen and Sommers, 1982) \\
\hline Exchangeable potassium (K) & 195 & $\mathrm{mg} \mathrm{kg}^{-1}$ & Barium chloride (Hendershot and Duquette, 1986) \\
\hline Exchangeable sodium $(\mathrm{Na})$ & 186 & $\mathrm{mg} \mathrm{kg}^{-1}$ & Barium chloride (Hendershot and Duquette, 1986) \\
\hline Exchangeable calcium (Ca) & 2611 & $\mathrm{mg} \mathrm{kg}^{-1}$ & Barium chloride (Hendershot and Duquette, 1986) \\
\hline Exchangeable magnesium & 47 & $\mathrm{mg} \mathrm{kg}^{-1}$ & Barium chloride (Hendershot and Duquette, 1986) \\
\hline \multicolumn{4}{|l|}{$(\mathrm{Mg})$} \\
\hline Available iron $(\mathrm{Fe})$ & 2.68 & $\mathrm{mg} \mathrm{kg}^{-1}$ & DTPA (Soltanpour and Schwab, 1977) \\
\hline Available manganese (Mn) & 1 & $\mathrm{mg} \mathrm{kg}^{-1}$ & DTPA (Soltanpour and Schwab, 1977) \\
\hline Available zinc ( $\mathrm{Zn})$ & 0.51 & $\mathrm{mg} \mathrm{kg}^{-1}$ & DTPA (Soltanpour and Schwab, 1977) \\
\hline Available copper $(\mathrm{Cu})$ & 2.21 & $\mathrm{mg} \mathrm{kg}^{-1}$ & DTPA (Soltanpour and Schwab, 1977) \\
\hline Available Boron (B) & 0.29 & $\mathrm{mg} \mathrm{kg}^{-1}$ & Calcium chloride (Bingham 1982) \\
\hline $\mathrm{C} / \mathrm{N}$ ratio & 8.03 & & \\
\hline Cation Exch. Capacity (CEC) & 14.7 & meq $100 \mathrm{~g}^{-1}$ & Barium chloride (Hendershot and Duquette, 1986) \\
\hline $\mathrm{pH}$ & 8.39 & & Water/Potentiometric \\
\hline
\end{tabular}




\begin{tabular}{|c|c|c|}
\hline Parameters & Value & Unit \\
\hline \multicolumn{3}{|l|}{ Physical properties } \\
\hline Moisture & 13.8 & $\%$ \\
\hline Bulk density & $0.43 \pm 0.04$ & $\mathrm{~g} \mathrm{~cm}^{-3}$ \\
\hline Hydrophobicity & $\begin{array}{c}\text { Slightly } \\
\text { hydrophobic }\end{array}$ & \\
\hline Total porosity & 2722 & $\mathrm{~mm}^{3} \mathrm{~g}^{-1}$ \\
\hline Transmission pores & 318 & $\mathrm{~mm}^{3} \mathrm{~g}^{-1}$ \\
\hline Storage pores & 1997 & $\mathrm{~mm}^{3} \mathrm{~g}^{-1}$ \\
\hline Residuals pores & 406 & $\mathrm{~mm}^{3} \mathrm{~g}^{-1}$ \\
\hline Max water absorption & 4.53 & $\mathrm{~g} \mathrm{~g}^{-1}$ of d.m. \\
\hline Skeletal density (SD) ${ }^{\mathrm{a}}$ & $1.86 \pm 0.04$ & $\mathrm{~g} \mathrm{~cm}^{-3}$ \\
\hline Envelope density $(\mathrm{ED})^{\mathrm{b}}$ & $0.246 \pm 0.006$ & $\mathrm{~g} \mathrm{~cm}^{-3}$ \\
\hline Porosity (ED/SD) & $0.863 \pm 0.006$ & $\%$ \\
\hline Surface area ${ }^{1}$ (BET Brunauer- & $410 \pm 6$ & $\mathrm{~m}^{2} \mathrm{~g}^{-1}$ \\
\hline $\begin{array}{l}\text { Emmett-Teller method) } \\
\text { Particle size distribution }(\mathrm{w} / \mathrm{w})^{\mathrm{c}}\end{array}$ & & $\%$ \\
\hline $50-20$ & 4.5 & $\%$ \\
\hline $20-10$ & 12.1 & $\%$ \\
\hline $10-8$ & 13.1 & $\%$ \\
\hline $8-4$ & 10.4 & $\%$ \\
\hline $4-2$ & 19.8 & $\%$ \\
\hline $2-1$ & 24.2 & $\%$ \\
\hline$<1$ & 15.9 & \\
\hline \multicolumn{3}{|l|}{ Chemical properties } \\
\hline $\mathrm{pH}$ & 9.8 & - \\
\hline CEC & 101 & cmolc kg $^{-1}$ \\
\hline Carbon $^{1}(\mathrm{C})$ & 778.0 & $\mathrm{~g} \mathrm{~kg}^{-1}$ \\
\hline Total nitrogen $(\mathrm{N})$ & 9.1 & $\mathrm{~g} \mathrm{~kg}^{-1}$ \\
\hline $\mathrm{C} / \mathrm{N}$ & 85.5 & - \\
\hline Aluminum (Al) & 268 & $\mathrm{mg} \mathrm{kg}^{-1}$ \\
\hline Arsenic (As) & 0.005 & $\mathrm{mg} \mathrm{kg}^{-1}$ \\
\hline Beryllium (Be) & 0.001 & $\mathrm{mg} \mathrm{kg}^{-1}$ \\
\hline Cadmium (Cd) & 0.001 & $\mathrm{mg} \mathrm{kg}^{-1}$ \\
\hline Calcium $(\mathrm{Ca})$ & 25.0 & $\mathrm{~g} \mathrm{~kg}^{-1}$ \\
\hline Chrome (Cr) & 0.002 & $\mathrm{mg} \mathrm{kg}^{-1}$ \\
\hline Cobalt (Co) & 0.002 & $\mathrm{mg} \mathrm{kg}^{-1}$ \\
\hline Copper $(\mathrm{Cu})$ & 97 & $\mathrm{mg} \mathrm{kg}^{-1}$ \\
\hline Iron $(\mathrm{Fe})$ & 333 & $\mathrm{mg} \mathrm{kg}^{-1}$ \\
\hline Magnesium (Mg) & 28.7 & $\mathrm{~g} \mathrm{~kg}^{-1}$ \\
\hline Manganese (Mn) & 84 & $\mathrm{mg} \mathrm{kg}^{-1}$ \\
\hline Molybdenum (Mo) & 2 & $\mathrm{mg} \mathrm{kg}^{-1}$ \\
\hline Phosphorus (P) & 23.3 & $\mathrm{~g} \mathrm{~kg}^{-1}$ \\
\hline Potassium (K) & 13.9 & $\mathrm{~g} \mathrm{~kg}^{-1}$ \\
\hline Sodium (Na) & 11.9 & $\mathrm{~g} \mathrm{~kg}^{-1}$ \\
\hline Sulphur (S) & 481 & $\mathrm{mg} \mathrm{kg}^{-1}$ \\
\hline Zinc $(\mathrm{Zn})$ & 104 & $\mathrm{mg} \mathrm{kg}^{-1}$ \\
\hline
\end{tabular}

3 a The skeletal density is the sample mass divided by sample volume occupied by a solid sample,

4 including any pores not accessible to the helium gas. ${ }^{\mathrm{b}}$ The envelope density is defined as the sample 
5 mass divided by the total sample volume that is measured if an "envelope" would be placed around 6 each individual particle. "data from Baronti et al. (2014) (with permission). 
7 Table 3. Rate and timing of the treatments. Fertilization strategies were applied either to vines

8 grown in unamended soil or to soil amended with biochar as in a factorial experimental

9 design.

\begin{tabular}{|c|c|c|c|}
\hline $\begin{array}{l}\text { Fertilization } \\
\text { strategies }\end{array}$ & Rate & Doses of $\mathrm{Fe}$ & Timing \\
\hline Control & & - & - \\
\hline $\begin{array}{l}\text { Soil-applied Fe- } \\
\text { chelate } \\
(\text { Fe-EDDHA - Fe 6\%) }\end{array}$ & $\begin{array}{l}1.0 \mathrm{~g} \mathrm{~L}^{-1} \\
(200 \mathrm{~mL} \\
\left.\text { application }^{-1}\right)\end{array}$ & $\begin{array}{l}9.2 \mathrm{mg} \text { and } 11.5 \mathrm{mg} \mathrm{Fe} \\
\mathrm{kg}^{-1} \text { soil in the first and } \\
\text { second season, } \\
\text { respectively }\end{array}$ & $\begin{array}{l}\text { From bud burst, } 4 \text { and } 5 \\
\text { applications by fertigation in } \\
\text { the first and second season, } \\
\text { respectively (every } 15 \text { days) }\end{array}$ \\
\hline $\begin{array}{l}\text { Synthetic Siderite } \\
\left(\mathrm{FeCO}_{3}\right)\end{array}$ & $1 \mathrm{~g} \mathrm{~kg}^{-1}$ & $481 \mathrm{mg} \mathrm{Fe} \mathrm{kg}^{-1}$ soil & $\begin{array}{l}\text { Single application, at } \\
\text { transplanting }\end{array}$ \\
\hline $\begin{array}{l}\text { Aqueous vegetal } \\
\text { extract of Amaranthus } \\
\text { retroflexus }\end{array}$ & $\begin{array}{l}30 \mathrm{~g} \mathrm{~L}^{-1} \\
(200 \mathrm{~mL} \\
\left.\text { application }^{-1}\right)\end{array}$ & - & $\begin{array}{l}\text { From bud burst, } 4 \text { and } 5 \\
\text { applications by fertigation in } \\
\text { the first and second season, } \\
\text { respectively (every } 15 \text { days) }\end{array}$ \\
\hline $\begin{array}{l}\text { Aqueous vegetal } \\
\text { extract of Amaranthus } \\
\text { retroflexus }+\mathrm{FeSO}_{4}\end{array}$ & $\begin{array}{l}30 \mathrm{~g} \mathrm{~L}^{-1}+2 \mathrm{~g} \mathrm{~L}^{-1} \\
(200 \mathrm{~mL} \\
\left.\text { application }^{-1}\right)\end{array}$ & $\begin{array}{l}61.5 \text { e } 76.9 \mathrm{mg} \mathrm{Fe} \mathrm{kg}^{-1} \\
\text { soil in the first and } \\
\text { second season, } \\
\text { respectively }\end{array}$ & $\begin{array}{l}\text { From bud burst, } 4 \text { and } 5 \\
\text { applications by fertigation in } \\
\text { the first and second season, } \\
\text { respectively (every } 15 \text { days) }\end{array}$ \\
\hline
\end{tabular}

10 


\begin{tabular}{|c|c|c|c|}
\hline & \multicolumn{3}{|c|}{ Plant biomass at harvest } \\
\hline & Shoot & Stem+ Root & Total Dry \\
\hline & & & Biomass \\
\hline & $\left(\right.$ g dw plant $\left.^{-1}\right)$ & $\left(\mathrm{g} \mathrm{dw}_{\text {plant }}{ }^{-1}\right)$ & $\left(\right.$ g dw plant $\left.^{-1}\right)$ \\
\hline \multicolumn{4}{|l|}{ Fertilization } \\
\hline Control & $-{ }^{a}$ & $13.1 \mathrm{c}$ & $13.1 \mathrm{c}$ \\
\hline Fe-chelate & $18.2 \mathrm{a}$ & $50.6 \mathrm{ab}$ & $68.8 \mathrm{a}$ \\
\hline Siderite & $12.2 \mathrm{~b}$ & $42.2 \mathrm{~b}$ & $54.4 \mathrm{~b}$ \\
\hline A. retroflexus & - & $11.2 \mathrm{c}$ & $11.2 \mathrm{c}$ \\
\hline A. retroflexus $+\mathrm{FeSO}_{4}$ & $13.3 \mathrm{ab}$ & $51.3 \mathrm{a}$ & $64.6 \mathrm{a}$ \\
\hline \multicolumn{4}{|l|}{ Biochar $\left(\mathrm{g} \mathrm{kg}^{-1}\right)$} \\
\hline 0 & 15.3 & 34.9 & 50.2 \\
\hline 50 & 13.9 & 31.0 & 44.9 \\
\hline \multicolumn{4}{|l|}{ Significance ( $p$ values) } \\
\hline Fertilization & 0.033 & $<0.0001$ & $<0.0001$ \\
\hline Biochar & 0.385 & 0.374 & 0.292 \\
\hline Fert $x$ Biochar & 0.338 & 0.595 & 0.684 \\
\hline
\end{tabular}

${ }^{a}$ At the end of the experiment, shoots from the untreated control and A. retroflexus alone treated plants

21 were not present because plants had died.

22 When a significant effect occurred, means in the same column followed by the same letter are not

23 statistically different $(p<0.05$, SNK Test). 
Table 5. Effect of the fertilization and biochar on leaf macro and micronutrient concentration in July 2012

25

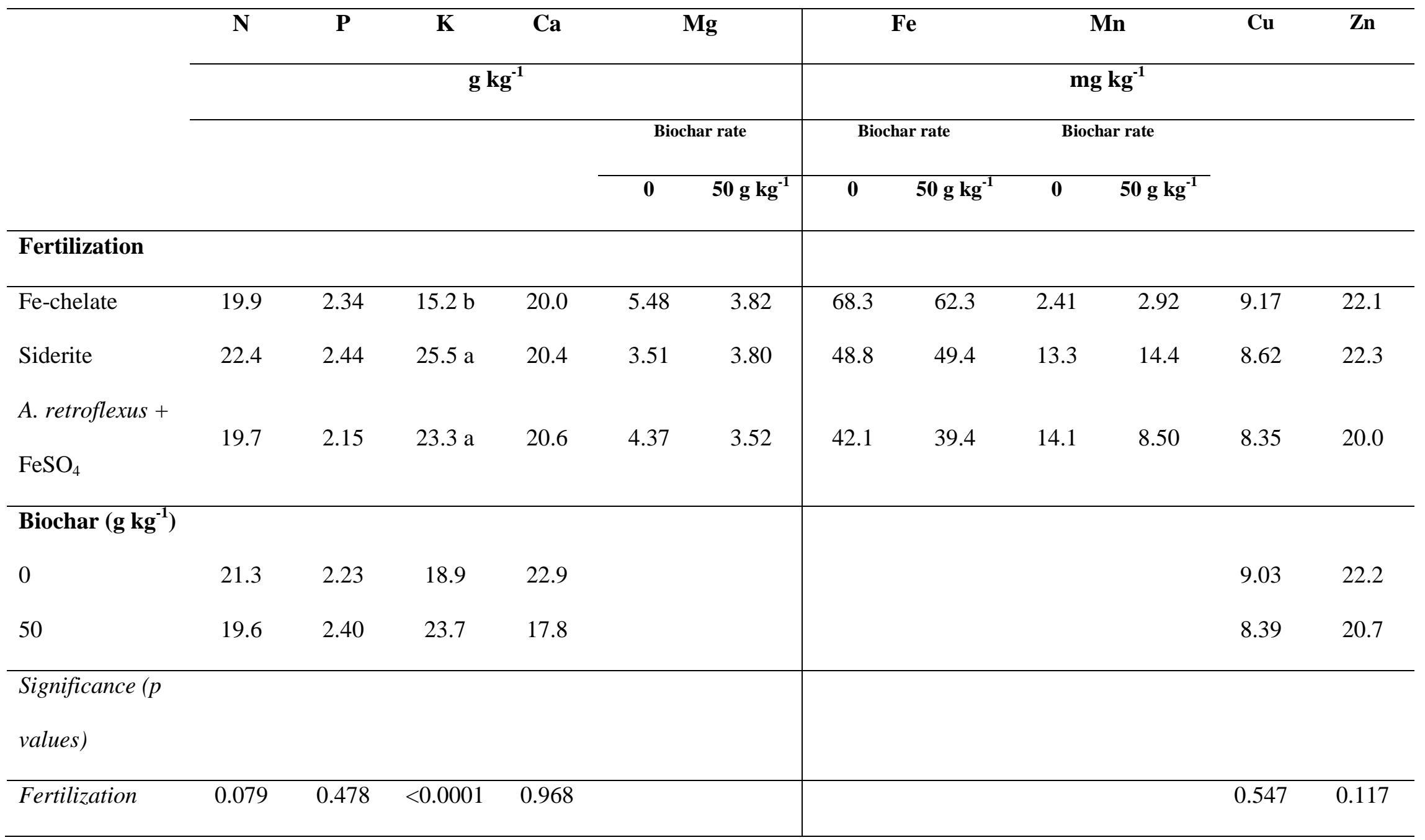




\begin{tabular}{lccccc|cccc}
\hline Biochar & 0.524 & 0.387 & 0.0006 & 0.016 & & & 0.906 & 0.125 \\
\hline Fert x Biochar & 0.192 & 0.363 & 0.095 & 0.327 & 0.048 & 0.030 & 0.002 & 0.357 & 0.080 \\
& & & & & $(2 S E M=0.75)$ & $(2 S E M=2.59)$ & $(2 S E M=2.41)$ &
\end{tabular}

26 When a significant effect occurred, means in the same column followed by the same letter are not statistically different $(p<0.05$, SNK Test)Within the same

27 nutrient, values differing by $\geq 2$ standard error of means (SEM) are statistically different. 
Table 6. Effect of the fertilization strategy and biochar on soil $\mathrm{pH}$, soil deionized water (DI-

$\mathrm{H}_{2} \mathrm{O}$ ) and DTPA extractable $\mathrm{Fe}, \mathrm{Mn}, \mathrm{Cu}$ and $\mathrm{Zn}$ at the end of the experiment

\begin{tabular}{|c|c|c|c|c|c|c|}
\hline \multirow[t]{2}{*}{ Fertilization } & \multirow[t]{2}{*}{ Soil pH } & DI-H $\mathrm{H}_{2} \mathrm{O}$ & \multicolumn{4}{|c|}{ DTPA extractable } \\
\hline & & $\mathbf{F e}$ & $\mathbf{F e}$ & Mn & $\mathbf{C u}$ & $\mathbf{Z n}$ \\
\hline & & \multicolumn{5}{|c|}{$\mathrm{mg} \mathrm{kg}^{-1}(\mathrm{dw})$} \\
\hline Control & $7.52 \mathrm{a}$ & $0.25 \mathrm{~b}$ & $1.94 \mathrm{c}$ & 5.20 & $2.63 \mathrm{a}$ & 2.04 \\
\hline Fe-chelate & $7.46 \mathrm{~b}$ & $0.53 \mathrm{a}$ & $2.36 \mathrm{bc}$ & 6.22 & $2.23 \mathrm{~b}$ & 1.79 \\
\hline Siderite & $7.48 \mathrm{~b}$ & $0.26 \mathrm{~b}$ & $2.90 \mathrm{~b}$ & 6.87 & $2.72 \mathrm{a}$ & 2.03 \\
\hline A. retroflexus & $7.59 \mathrm{a}$ & $0.32 \mathrm{~b}$ & $2.02 \mathrm{c}$ & 6.45 & $2.62 \mathrm{a}$ & 2.13 \\
\hline A. retroflexus + & $7.45 \mathrm{~b}$ & $0.20 \mathrm{~b}$ & $3.84 \mathrm{a}$ & 5.99 & $2.43 \mathrm{ab}$ & 1.87 \\
\hline \multicolumn{7}{|l|}{$\mathrm{FeSO}_{4}$} \\
\hline \multicolumn{7}{|l|}{ Biochar $\left(\mathrm{g} \mathrm{kg}^{-1}\right)$} \\
\hline 0 & 7.45 & 0.44 & 2.42 & 4.86 & 1.83 & 0.98 \\
\hline 50 & 7.56 & 0.19 & 2.80 & 7.46 & 3.23 & 2.97 \\
\hline \multicolumn{7}{|l|}{ Significance ( $p$} \\
\hline \multicolumn{7}{|l|}{ values) } \\
\hline Fertilization & 0.004 & 0.008 & $<0.0001$ & 0.079 & 0.020 & 0.329 \\
\hline Biochar & $<0.0001$ & $<0.0001$ & 0.014 & $<0.0001$ & $<0.0001$ & $<0.0001$ \\
\hline Fert $x$ Biochar & 0.124 & 0.537 & 0.202 & 0.404 & 0.350 & 0.804 \\
\hline
\end{tabular}



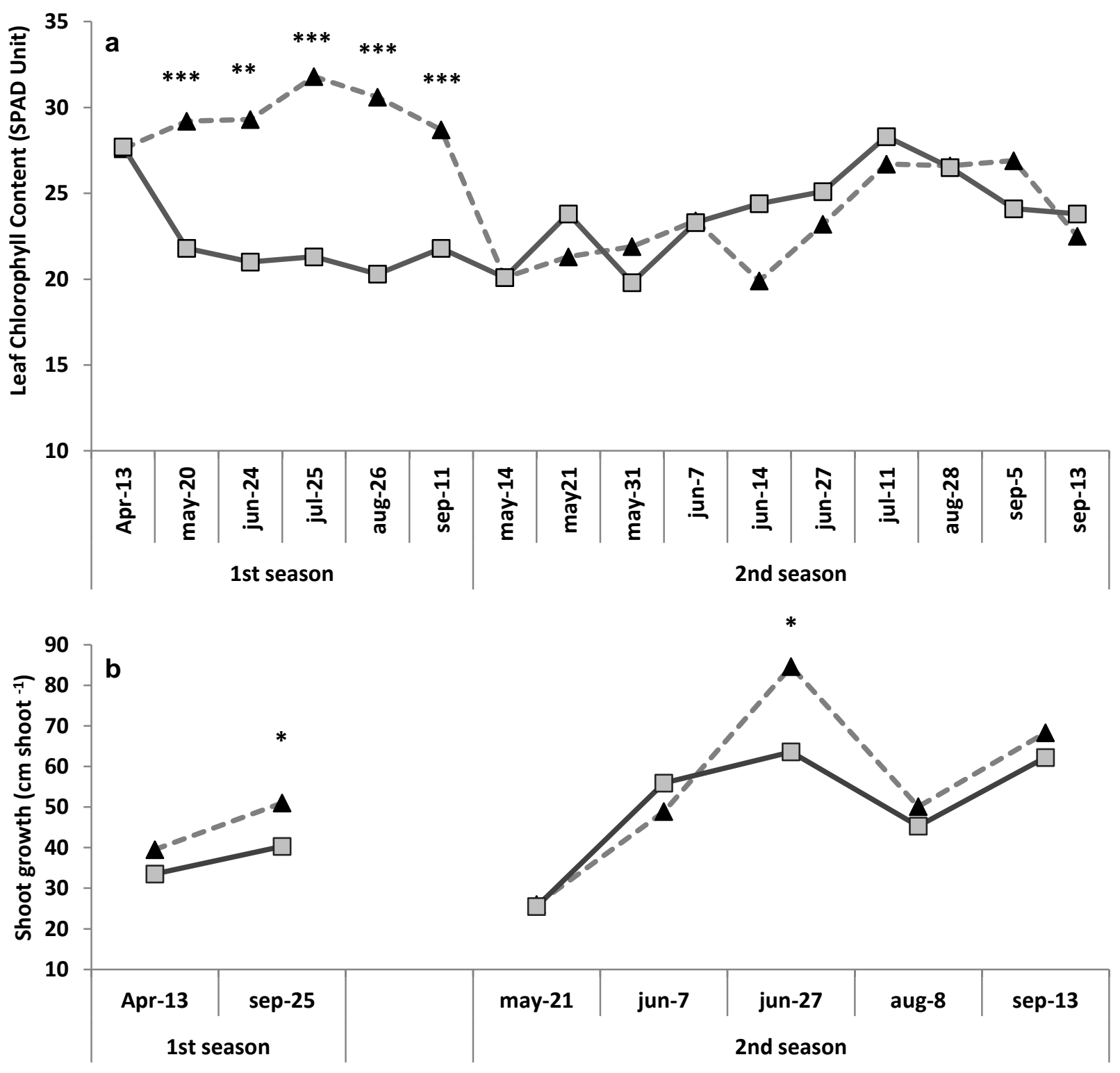

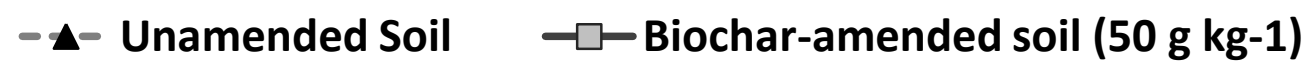



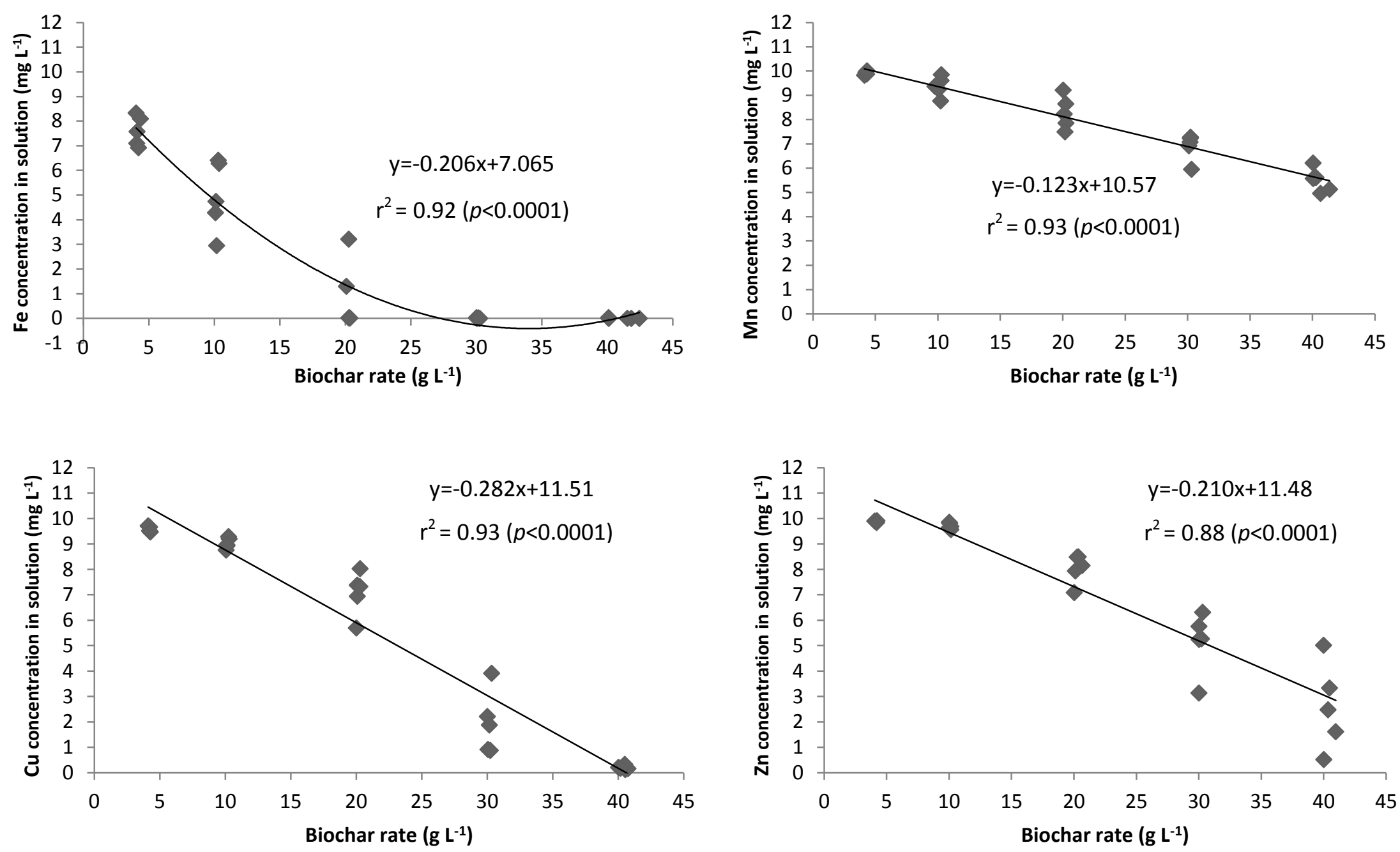


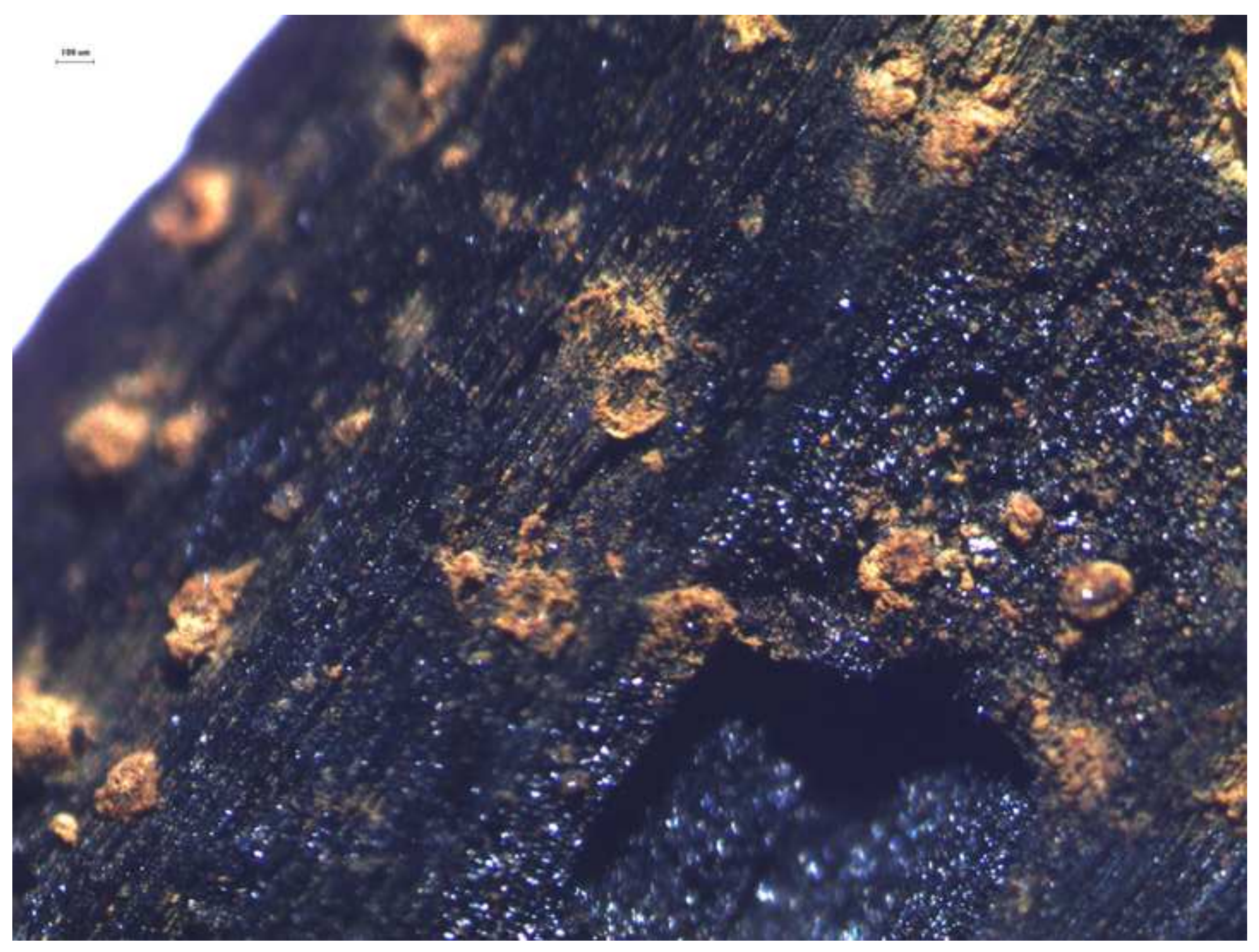

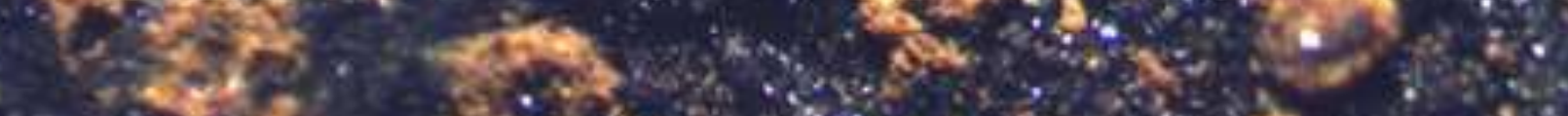

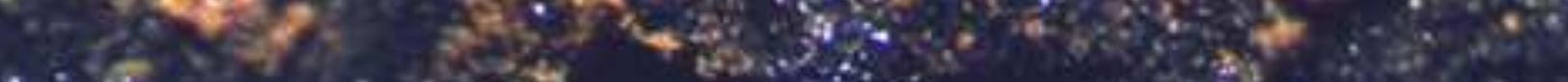
$\because-\frac{1}{2}+4$

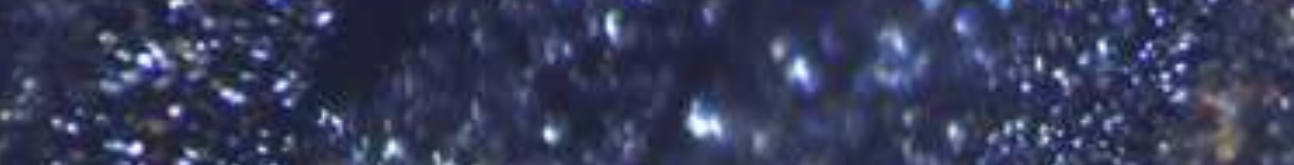
$\rightarrow x^{4}, x^{2}$ and

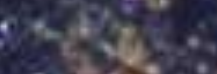
,

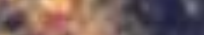
$y^{2}, 2,8$ (⿻)丨

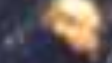

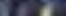
$x^{2} z^{2}$
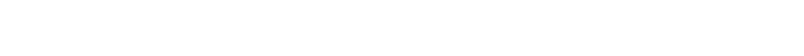


\section{FIGURE CAPTIONS}

2

3 Fig. 1 Effect of the amendment with biochar on leaf chlorophyll (Chl) content (a) and shoot growth

4 (b) throughout the experiment. Values are averages across fertilization strategies.

5

$6 * * *$ and $* * *=$ effect of the amendment significant at $p<0.05, p<0.01$ and $p<0.001$, respectively.

7

8 Fig. 2 Effect of increasing rates of biochar on $\mathrm{Fe}(\mathrm{A}), \mathrm{Mn}(\mathrm{B}), \mathrm{Cu}(\mathrm{C})$ and $\mathrm{Zn}(\mathrm{D})$ retention potential 9

$\mathrm{Fe}, \mathrm{Mn}, \mathrm{Cu}$ and $\mathrm{Zn}$ concentration in deionized water $\left(\mathrm{DI}-\mathrm{H}_{2} \mathrm{O}\right)$ was $0.022 \pm 0.002,0.016 \pm 0.01,0.0003 \pm$

$110.0001 \mathrm{mg} \mathrm{L}^{-1}$ and $<\mathrm{dl}($ avg. $\pm \mathrm{SE} ; \mathrm{n}=5)$, respectively. $\mathrm{Fe}, \mathrm{Mn}, \mathrm{Cu}$ and $\mathrm{Zn}$ concentration in solution was $9.28 \pm$ $120.036,10.05 \pm 0.0,9.88 \pm 0.0007$ and $10.01 \pm 0.0002 \mathrm{mg} \mathrm{L}^{-1}$ (avg. $\left.\pm \mathrm{SE} ; \mathrm{n}=5\right)$, respectively.

Fig. 3 Magnification (3.2x) of a biochar fragment recovered after 1-week exposure to a source of Fe. Likely due to redox reactions, typical rusted spots are clearly evident. The biochar surface (top $5 \mathrm{~nm}$ ) was then scanned by X-ray photoelectron spectroscopy (XPS). Magnification was obtained by an 